أزمة الهوية وعلاقتها بكل من ثقافة وسائل الاتصال والرضا عن الحياة في ضوء بعض المتفيرات الايموجر افية لاى طلاب جامعة

\title{
عين شمس
}

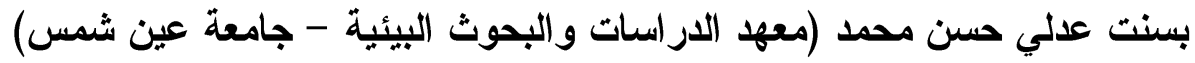

رشاد احمد عبد اللطيف (نائب رئيس جامعة حوان الأسبق)

ليلي أحمد السيد كرم (معهد الدراسات العليا للطفولة - جامعة عين شمس)

المستخلص المان

هدفت هذه الدراسة إلى التعرف على أهم ملامح أزمة الهوية ومستوى الرضا عـن

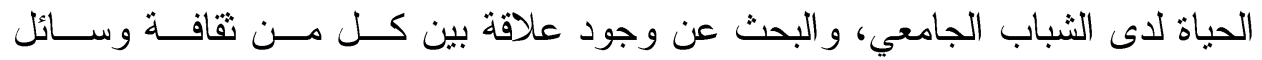
الاتصال و الرضا عن الحياة من جانب وأزمة الهوية من جانب آخر ، ولتحقيق ذلك قـام

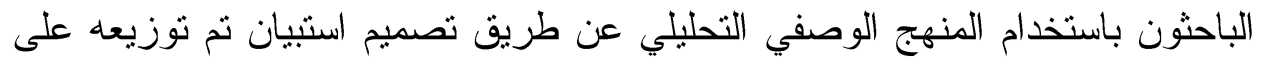

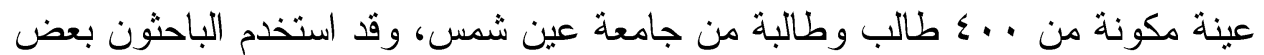

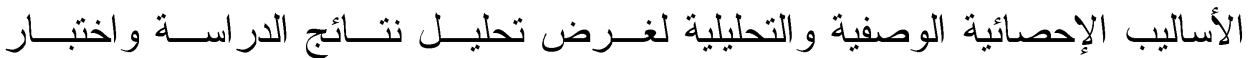

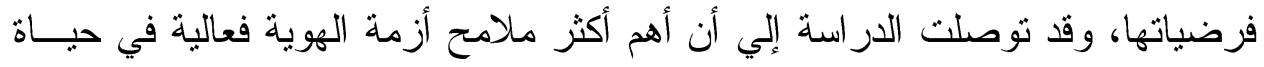

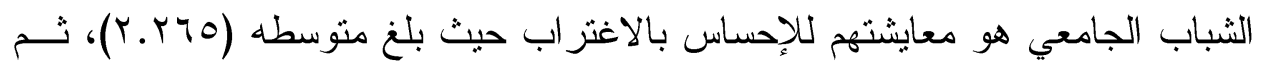

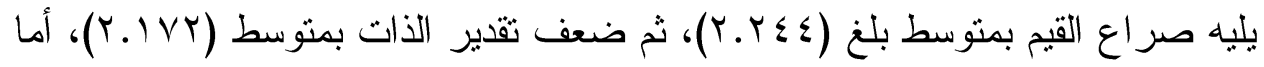

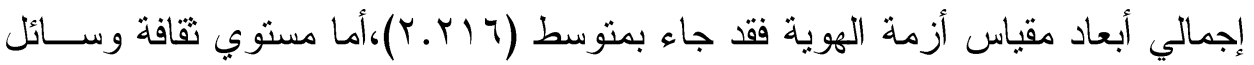

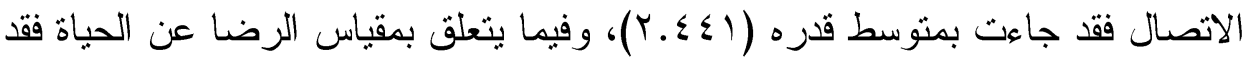

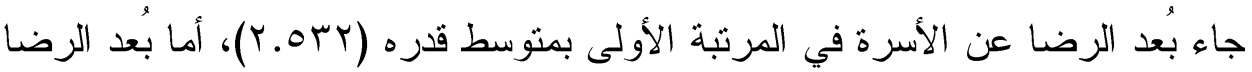

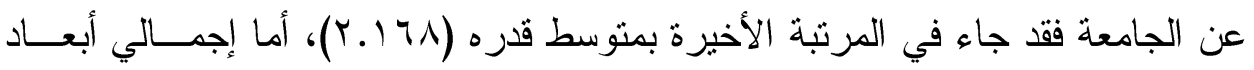

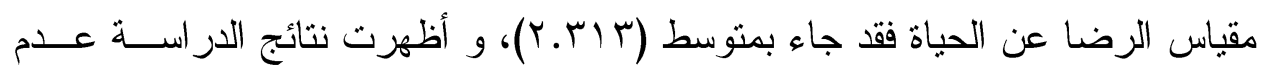
وجود فروق في أبعاد أزمة الهوية تبعا لبعض المتنغيرات الديمغر افية. 
أزمة الهوية وعلاقتها بكل من ثقافة وسائل الاتصال والرضا عن الحياة في ضوء بعض

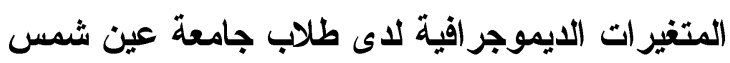

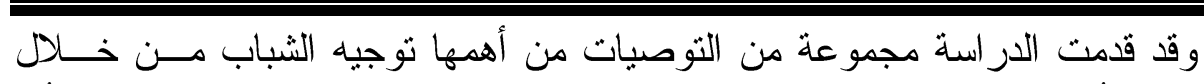
تبصيره بطرُ استغلال التطور التكنولوجي بإيجابياته بدل اهتمامه بالقشور التي تشألُبه

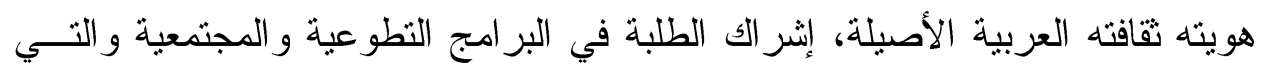

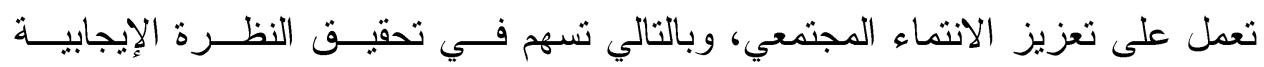
و المتفائلة نحو الحياة.

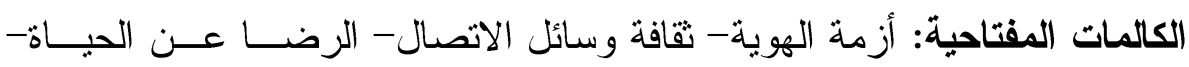
المتغير ات الديموجر افية - طلاب جامعة عين شمس. 


\section{The Crisis of Identity among University Youth in} Terms of the Environmental Changes and Contemporary Challenges and the Proposed Approaches to Psychologically Encounter Them (A Field Study on Ain Shams University) Basant Adly Hassan ()

Mohamed Rahsad Ahmed Abdel Latif (Ex-Vice-President of Helwan University)

Laila Ahmed Karm El-Din (Faculty of Post Graduate Childhood Studies - Ain shams university) ABSTRACT

This study aimed to identify the most important features of the identity crisis and the level of satisfaction with life among university youth, and to search for a relationship between each of the means of communication and satisfaction with life on the one hand and the identity crisis on the other side, and the sample consisted of 400 students from Ain Shams University, The study concluded that the most important feature of the identity crisis is most effective in the life of university students is their experience of feeling alienated, as it averaged (2.265), then followed by a conflict of values with an average of (2.244), then poor self-esteem with an average of $(2,172)$, and the total dimensions of the scale The identity crisis came with an average of (2.216). As for the level of culture of means of communication, it came with an average The amount of (2.441), and with regard to the measure of satisfaction with life, the distance of satisfaction with the family came in the first place with an average of (2.532), and the distance of satisfaction with the university came in the last rank with an average of (2.168), while the total dimensions of the measure of satisfaction with life were It came with an average of (2.313). The study presented a set of recommendations, the most important of which is to guide young people through insight into the ways of exploiting technological development with its positives instead of caring for the crusts that harbor its identity and authentic Arab culture. 
أزمة الهوية وعلاقتها بكل من ثقافة وسائل الاتصال والرضا عن الحياة في ضوء بعض

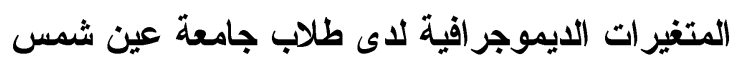

أزمة الهوية وعلاقتها بكل من ثقافة وسائل الاتصال و الرضا عن الحياة في ضوء بعض المتغيرات الايموجر افية لاى طلاب جامعة عين شمس

بسنت عدلي حسن محمد (معهد الدراسات والبحوث البيئية - جامعة عين شمس) رشاد احمد عبد اللطيف (نائب رئيس جامعة حلوان الأسبق)

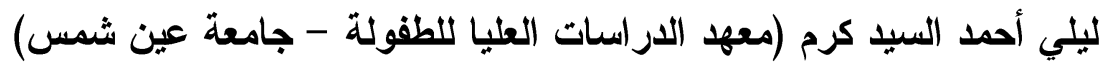
المقدمة

يعيش الثباب في عالمنا العربي اليوم مجموعة من التحولات في طــرق العـبش

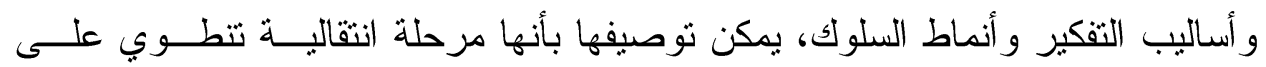
التداخل بين الثقليدي و الحديث، سواء على صعيد العلاقات الاجتماعية، أو الثقافية و القيم

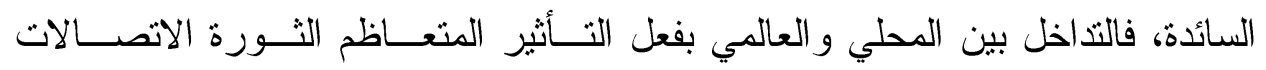
و المعلومات قد انعكس على مختلف الثر ائح الاجتماعية.

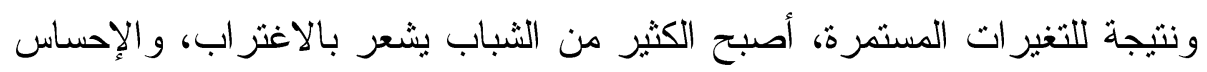

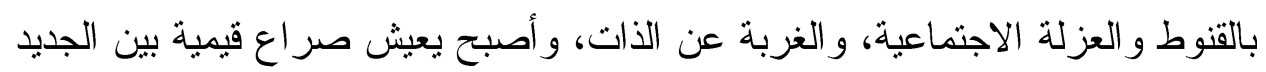

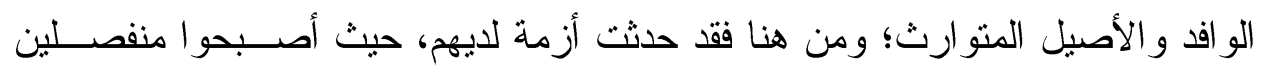

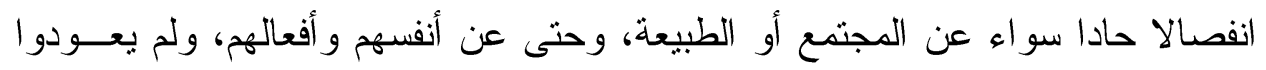

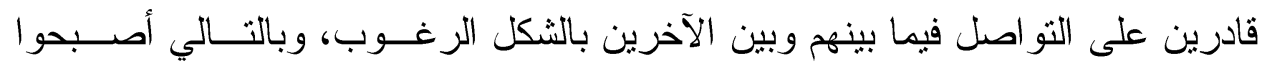

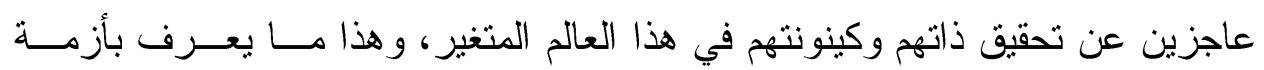
الهوية لدى الثباب.

ومن هنا أصبحت دراسة أزمة الهوية وعلاقتها بثقافة وسائل الاتصال لاى الثباب الثاب الثاب

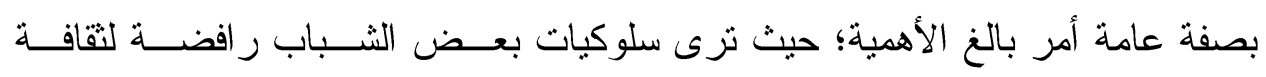




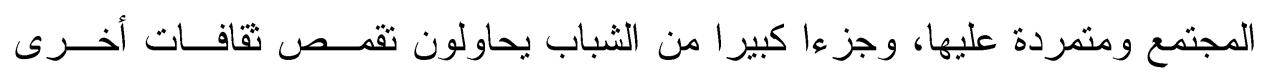

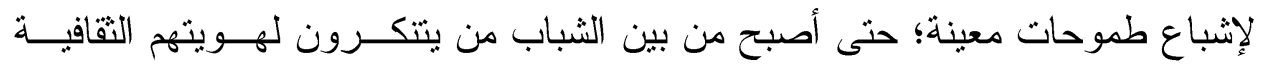

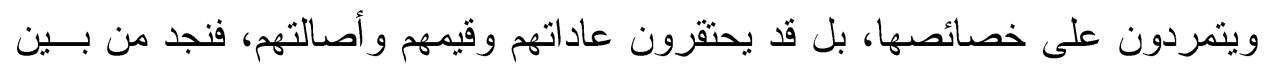

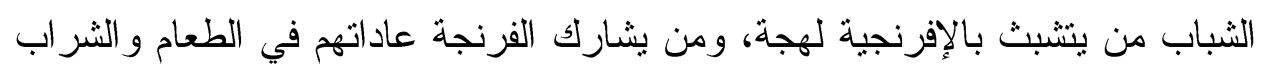

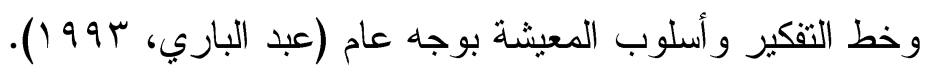
كما أن أزمة الهوية تعد نتيجة منوقعة للإخفاق في تحديد الهوية، أي أن الفرد غير اعبد قادر على تحديد مستقبله المهني و التعليمي، كما يتضمن شعوره بالاغتر اب وعدم وجود

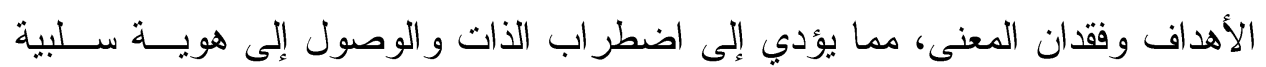
تقتقر إلى العلاقات البين شخصية (Mahmoud, 2011) وتعد أهم أهداف التعليم هـــو لهو

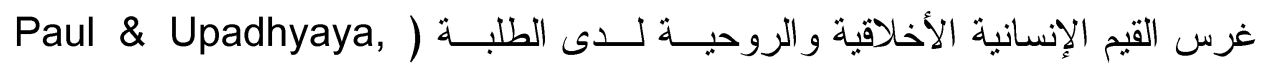
. $(2017$

يطمح الناس لتحقيق درجة عالية من الر احة النفسية من خلال الحد مـن تجـــاربهم

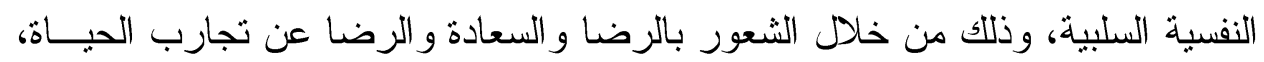

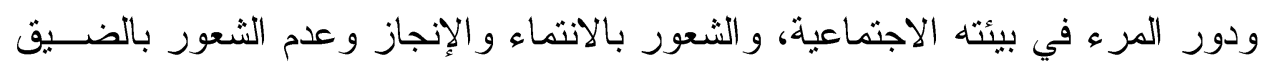

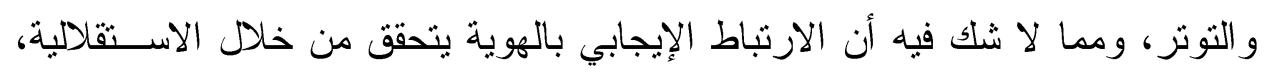

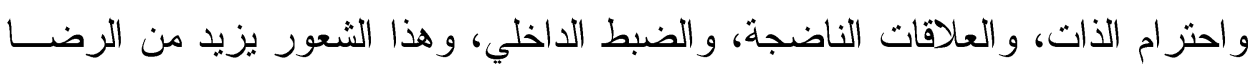
عن الحياة.

\section{مشكلة الدر اسة}

في ضوء ما تموج به الدول العربية من تغيرات وصر اعات بين القـيم الروحيــة

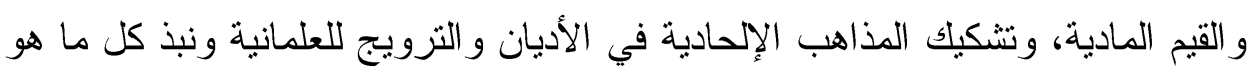
غيبي أو روحي و السعي إلى ترسيخ قيم العولمة، وفي ضو ء ما أثرت به الثورة العلمية

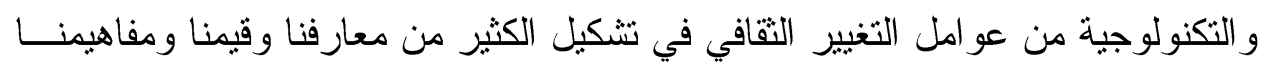

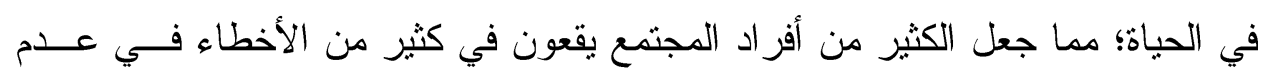




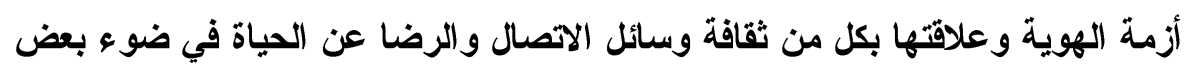

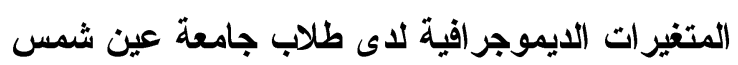

التمييز بين ما هو صواب وما هو خطأ، وبالتالي ضعف قدرتهم على الانتقاء و التقضيل

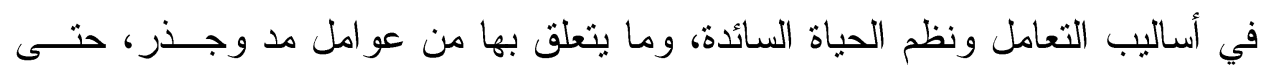
أصبح الشباب في أزمة حقيقية. و إنه ما يزيد من خطورة هذه الأزمة أن الهوية تعد من أكثر الحاجـات الإنسـانية

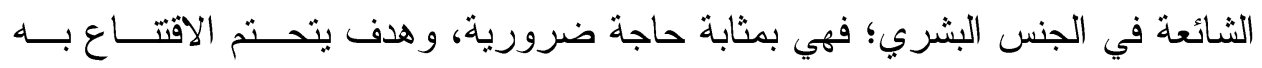

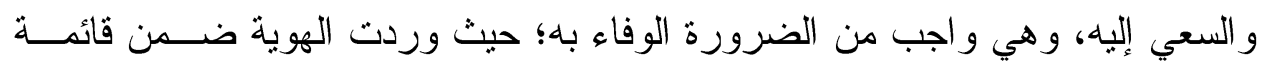

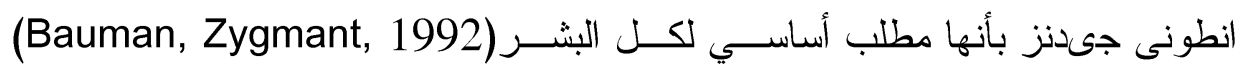

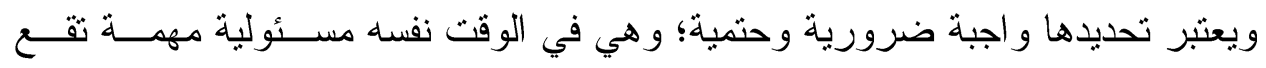
جزئيا على عاتق المسئولين، الذين بدور هم عليهم مهمة ضبطها وتوجيهها؛ على وهئ اعتبار أن شكل ومضمون الهوية من أهم الواجبات التي لا يمكن تجاهلها و التخلي عنها.

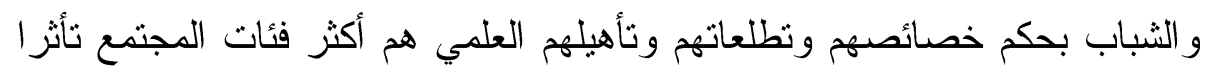

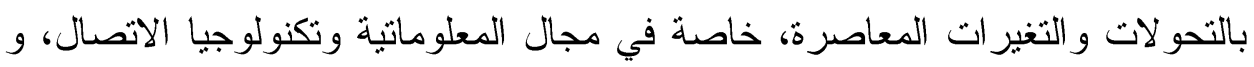

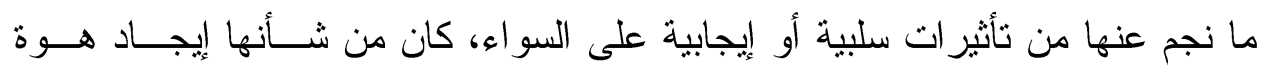

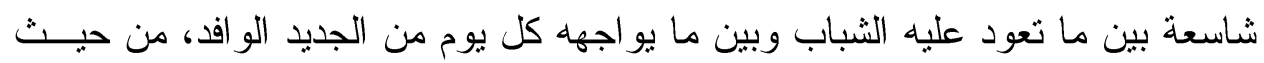

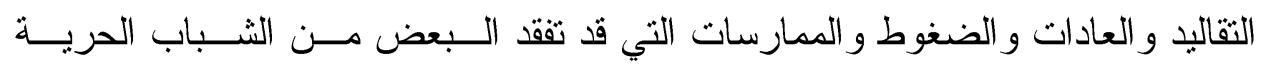

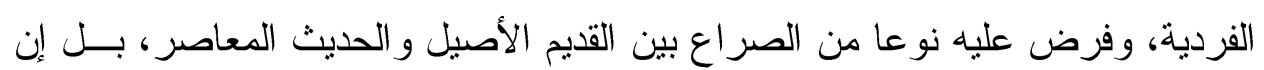
هذا كان من شأنه أن فرض عليه نوعا من الانعز الية وما تبعها من فقدان الشخصية، أو الأولئ

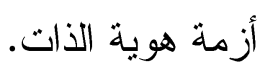
و إذا كانت أزمة الهوية تُعد أهم مشكلات مرحلة المر اهقة و الثباب كما يذكر العديد

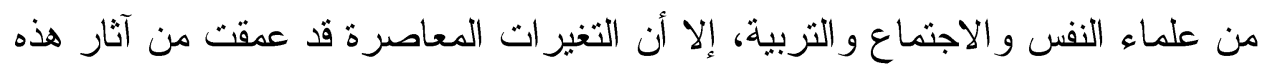
الأزمة، ووضعت لها ملامح و أبعادا متعددة.

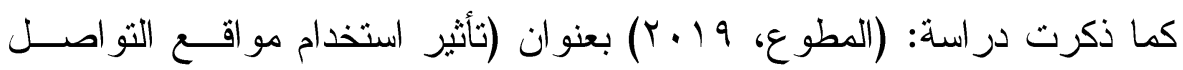

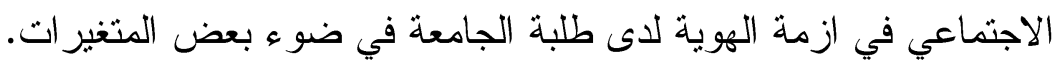


ودر اسة: (Parkk, 2019) بعنوان (نموذج لتطوير الهوية في مجموعة ثقافية مسن

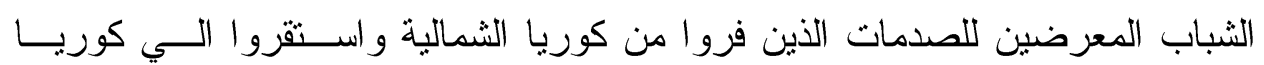

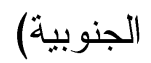

\section{أسئلة (الار اسةة}

السؤال الرئيسي: ما أهم ملامح أزمة الهوية عند الثباب الجامعي المصري في ظل

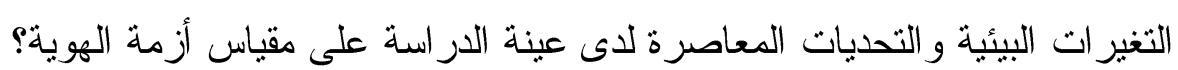
يتفرع من هذا التسؤل التساؤلات الفرعية التالية:

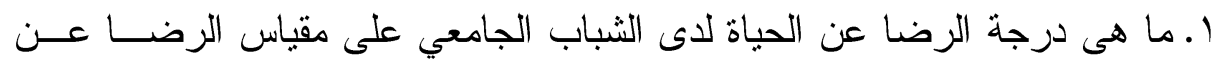
الحياة؟

r. هل تختلف ثقافة وسائل الاتصال باختلاف أزمة الهوية لاى الشباب الجامعي؟ r. هل توجد علاقة بين ثقافة وسائل الاتصال و ازمة الهوية لدى الثباب الجامعي؟

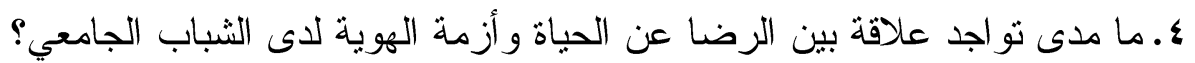

\section{أهداف الار اسة}

هدفت الار اسة الحالية التعرف على:

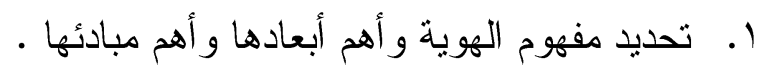

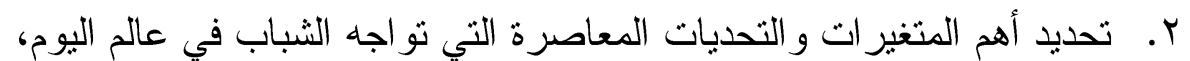

و أهم آثار ها على أزمة الهوية عند الثباب الجامعي المصري ل

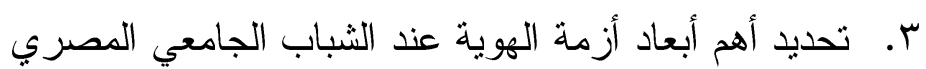

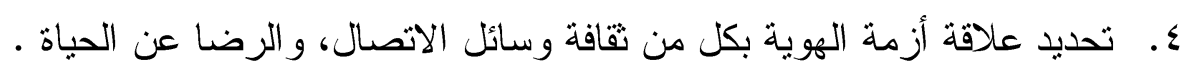

ه. تحديد وضع مجموعة من التوصيات و المقترحات التي تعزز دور المؤسسات

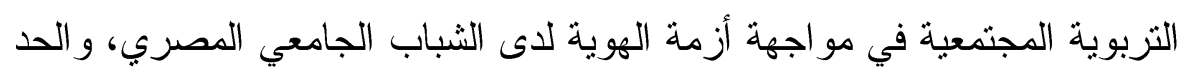

$$
\text { من آثار ها. }
$$

7. تحديد محاولة متو اضعة لإثر اء البحث العلمي في مجال العلوم الانسانية البيئية. 
أزمة الهوية وعلاقتها بكل من ثقافة وسائل الاتصال والرضا عن الحياة في ضوء بعض

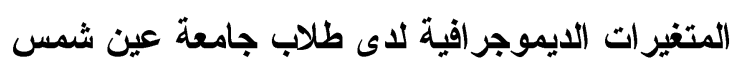

\section{أهمية الاراسة}

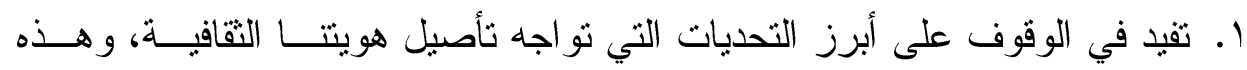

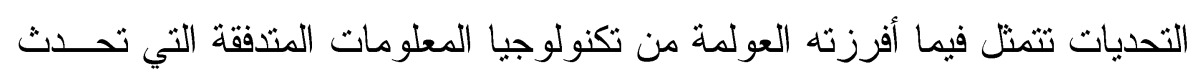

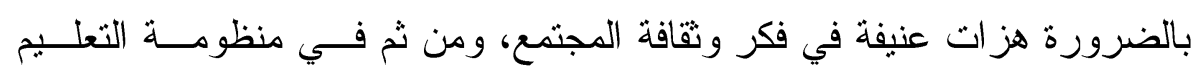

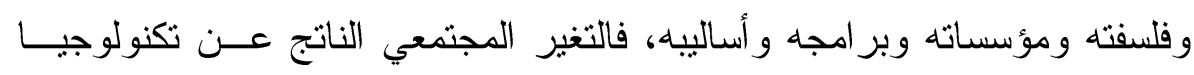

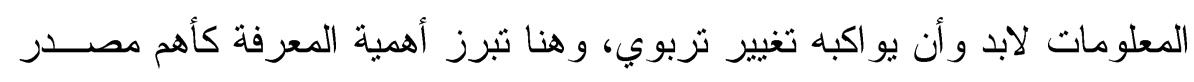

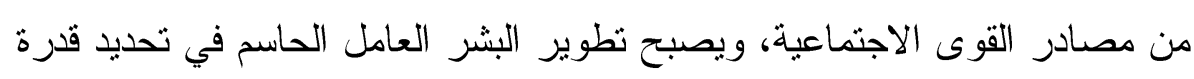

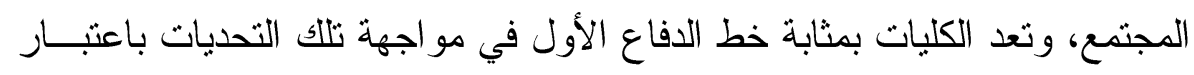
أنها المسؤولة عن صناعة البشر و إعداد القادة القادرين على تشكيل الهوية الثقافية لأبناء المستقبل.

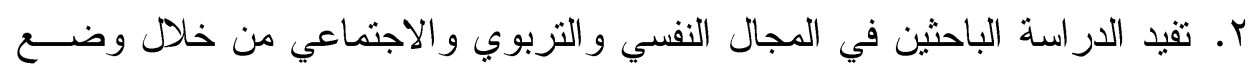

$$
\text { بر امج ارشادية وتدريبية لمو اجهة ازمة الهوية. }
$$

\& ثقافة وسائل الاتصال

تشير ثقافة وسائل الاتصال بوجه عام إلى الثقافة المميزة للمجتـــع الجمــاهيري، وجماهير ها نستهلك وتتمتع بثقافة تختلف اختلافا جوهريا عن الثقافة التي كانت محسل استماع (في الحاضر والماضي) لأن عناصر في الثقافة تنتقل وتتنشر من خلال وسائل الاتصال الحديثة (الهيتي، ب . بr)، وتعرف الباحثة ثقافة وسائل الاتصال إجر ائياً بأنها:

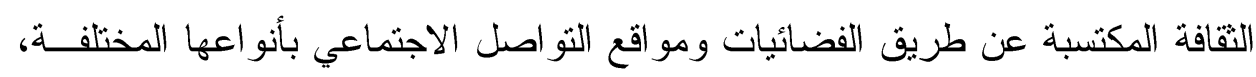

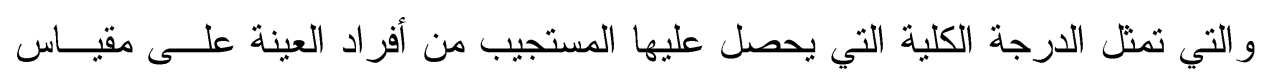
ثقافة وسائل الاتصال المستخدم في هذه الدر اسة. 


\section{> أزمة الهوية}

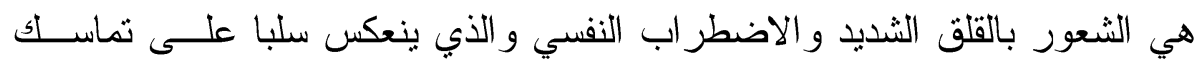

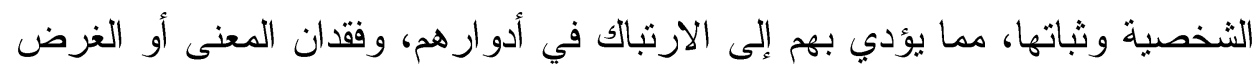
من حياتهم، و عدم معرفة إلى من ينتمون (Dameshghi,2016)، ويعرفها ماير بأنها درجة القلق و الاضطر اب المختلط المرتبطة بمحاولة المر اهق تحديد معنى لوجوده فــي

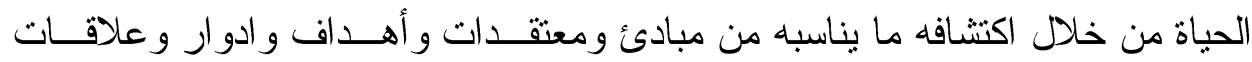

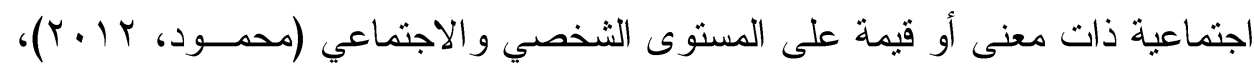

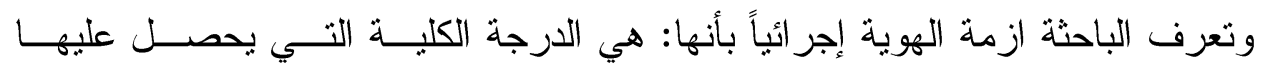
المستجيب من أفر اد العينة على مقياس أزمة الهوية المستخدم في هذه الدراسة.

\section{ه الرضا عن الحياة}

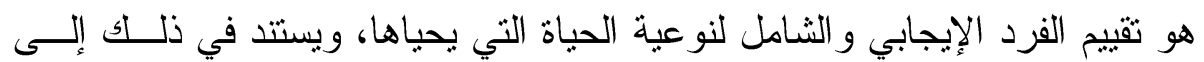

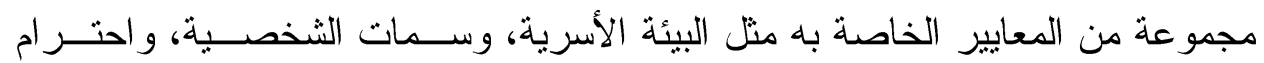

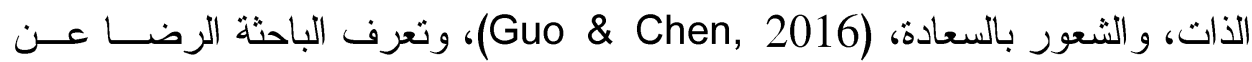
الحياة إجر ائياً بأنها: هو الدرجة الكلية التي يحصل عليها المستجيب من أفــراد العينـــة على مقياس الرضا عن الحياة المستخدم في هذه الدراسة. الار اسات السابقة

\section{أولا: الدراسَات العرَبيّة

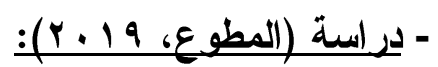

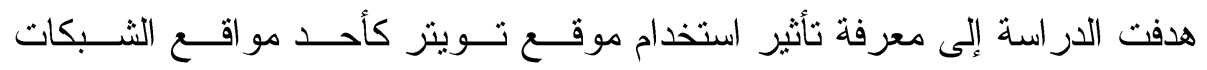
الاجتماعية في أزمة الهوية لدى طلاب وطالبات، وقد أظهرت نتائج الدر اسة وجود أثر مئر

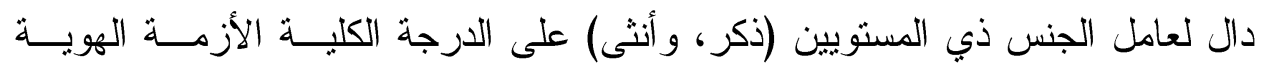

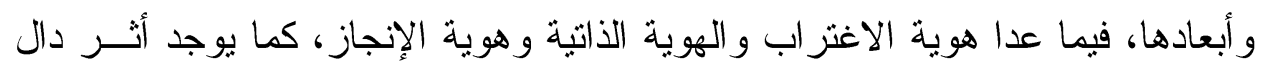


أزمة الهوية وعلاقتها بكل من ثقافة وسائل الاتصال والرضا عن الحياة في ضوء بعض

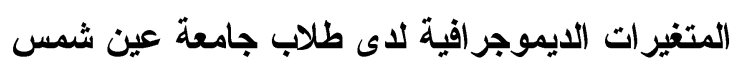

لعامل نوع المسار ذي المستويات الثلاثة (الصحي، و الهندسي، و العلمي) على الدرجــة الكلية لأزمة الهوية وأبعادها، فيما عدا هوية الاغتر اب و الهوية الذاتية وهوية الإنجاز .

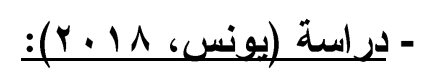

هدفت الدراسة إلى التعرف على العلاقة بين أزمة تشكل الهوية و الصلابة النفسـية

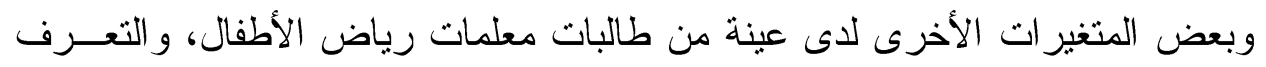

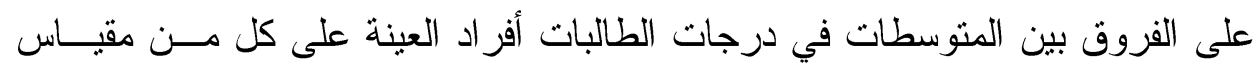

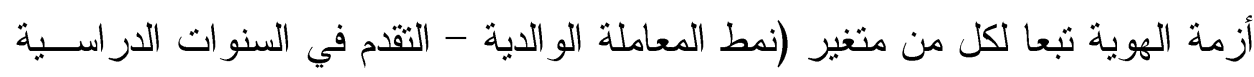

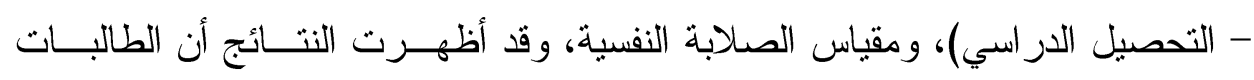

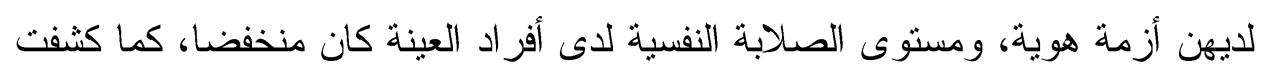

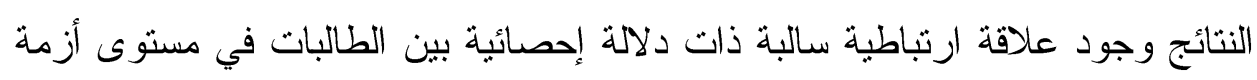

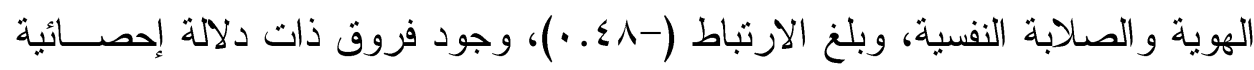

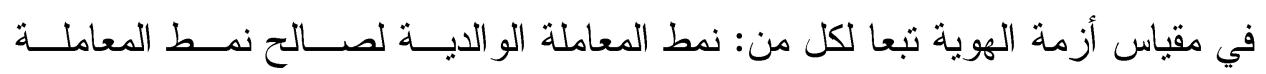

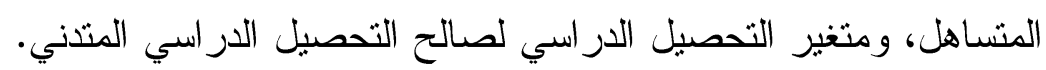

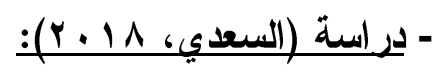

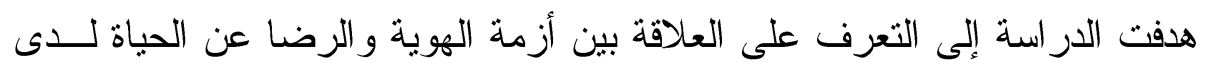

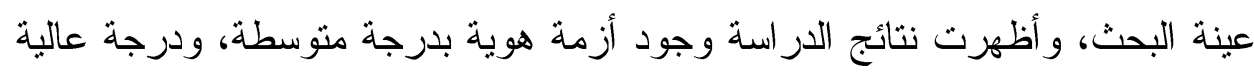

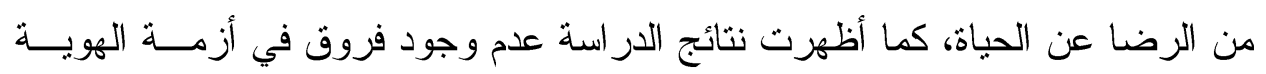

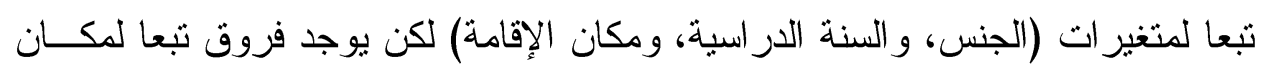

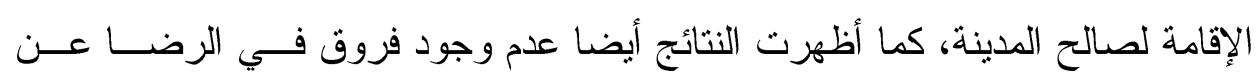
الحياة تبعا لمتغير ات (الجنس، و السنة الدر اسية، ومكان الإقامة) 


\section{دراسة (Dombrovskis, 2016)}

هدفت هذه الدر اسة إلى إيجاد رو ابط بين أزمات الهوية و المؤشــــرات الاجتماعيــة و الديموغر افية لطالبات السنة الأولى في جامعات لاتفيا، وقد أظهرث نتائج البحث عـن لهن

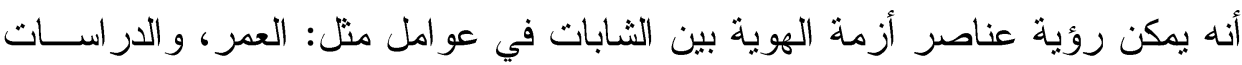

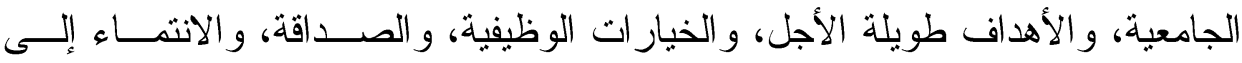

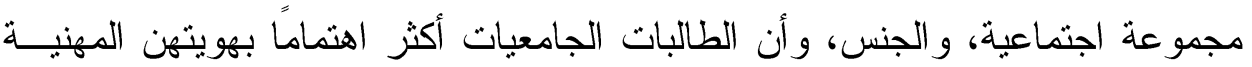

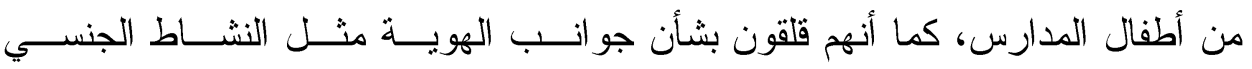
و العلاقات، لأن مسألة إقامة نوازن بين العمل و أهداف الأسرة هو المهر.

\section{دراسة (Nair, James et al. 2015):}

هدفت هذه الدر اسة إلى التعرف على ما إذا كانت التجارب التعسفية قبل أو خــلال فترة المر اهقة تساهم في شدة أزمة الهوية وما إذا كان أسلوب الأبوة و الاعم الاجتماعي لهابي يحدان من الأزمة، وقد أظهرت نتائج البحث وجود علاقة ارتباط إيجابية معتدلـــة بــين

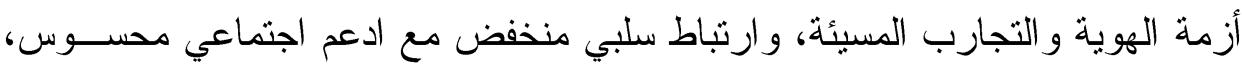

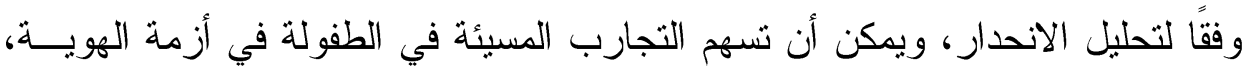
لكن الدعم الاجتماعي يمكن أن يقلاها.

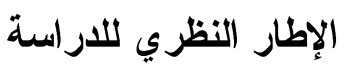
أولا: أزمة الهوية الهمطمان 1

يري ماير أن أزمة الهوية تتطوي على الإحساس بــالاغتر اب، وعــدم الجـدوى،

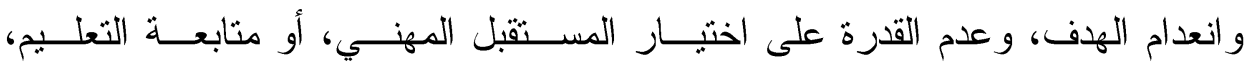
و اضطر اب الثخصية (Maier, 1995) ، ويربط بول جودمان بين أزمة الهوية وبـين 


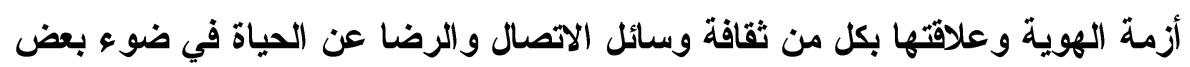

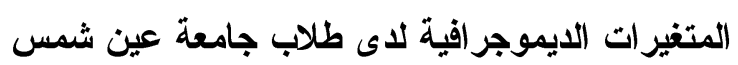

فقدان المر اهق أو الثاب للقيمة الاجتماعية من خلال دور اجتماعي، حيث بــدأ أزمسـة

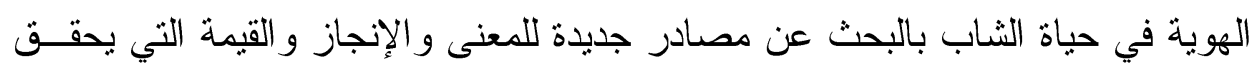

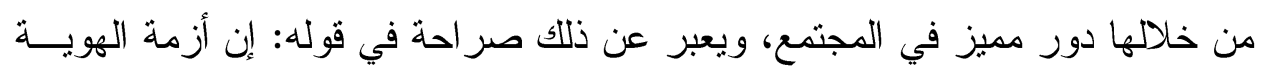

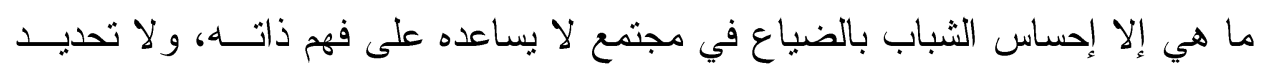

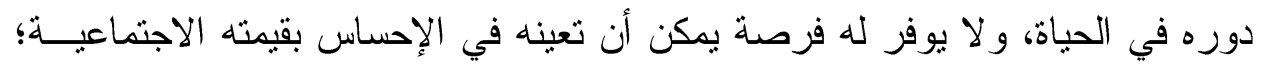

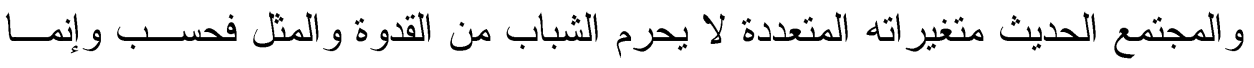

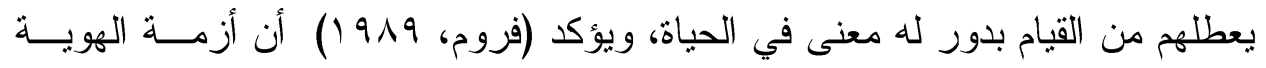

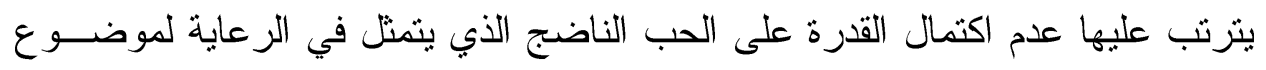

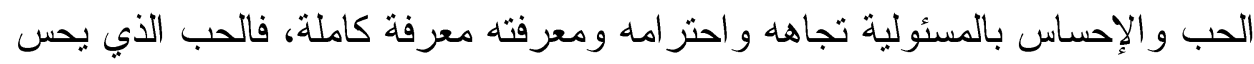
به الإنسان في بداية الثباب هو حب يتميز بالنقص لتعثر الثاب وتعقد أزمته مع نفســـهـ

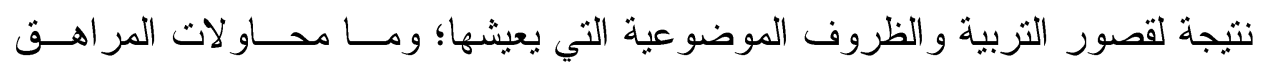

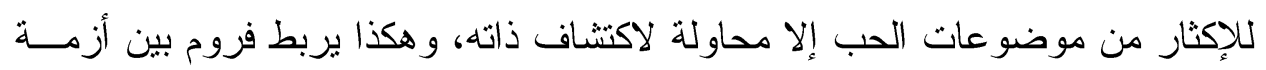
الهوية وفقدان القدرة على الحب الناضج.

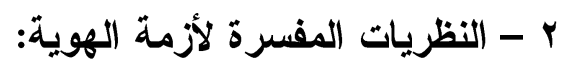

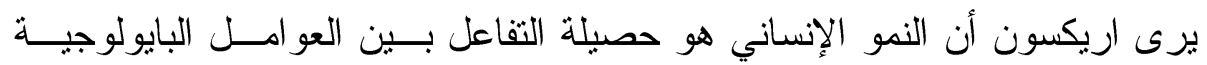

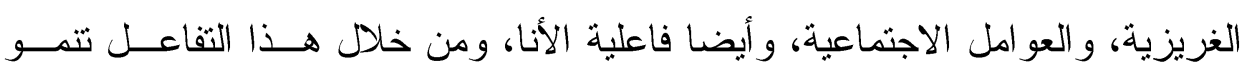

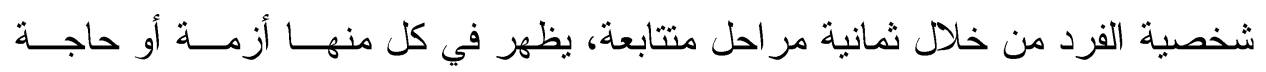

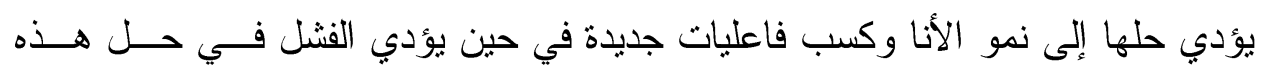

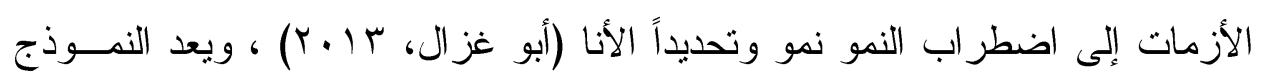

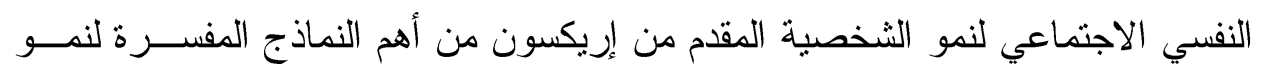

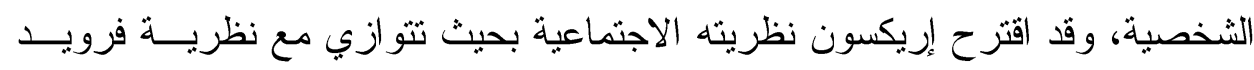

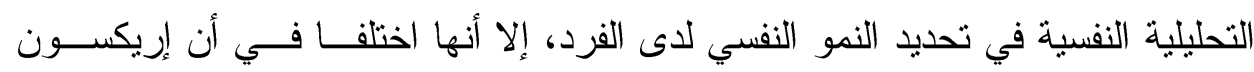

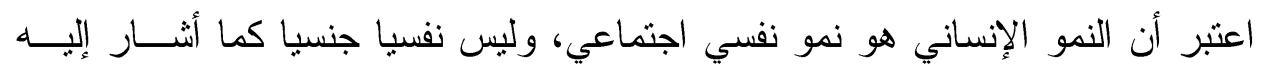


فرويد، و اتفق مع فرويد في أن (الأنا) هي الأساس في تشكيل شخصية الإنسان وتقـدم

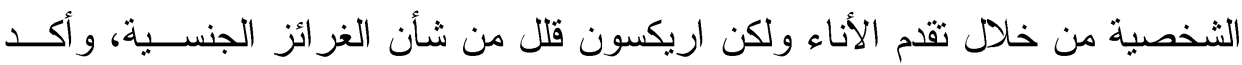
على أهمية الجانب الاجتماعي في النمو النفسي للإنسان، و أكد على امــتلالك الإنســان

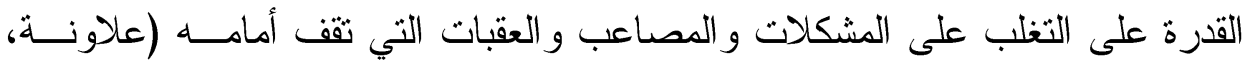
ـ . . ب)، ويرى إريكسون بان الهوية النفسية هي بمثابة المجموع الذي يحــوي جميــع

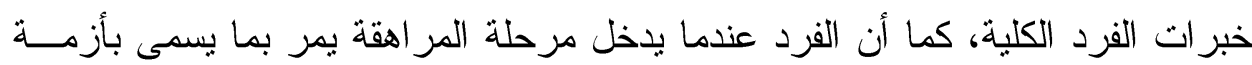

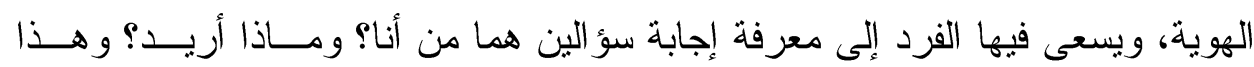

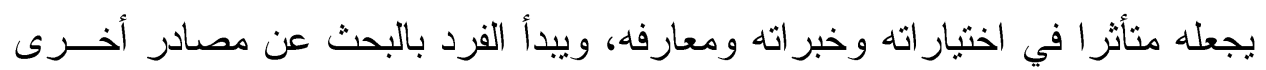

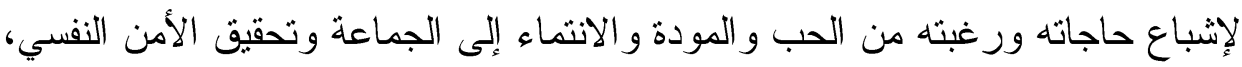

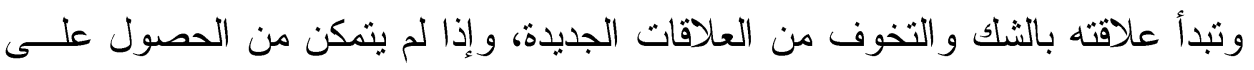

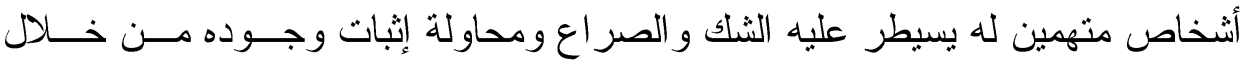
الاستقلال عن الأسرة أو الأصدقاء أو المجنمع (Erikson, 1980). r - أبعاد أزمة الهوية في حياة الشباب: بعد ضعف تقدير الـــات: مفهوم الذات يمثل الجزء المعرفي لمعرفة الذات، و تقدير

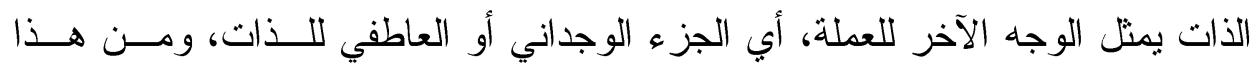

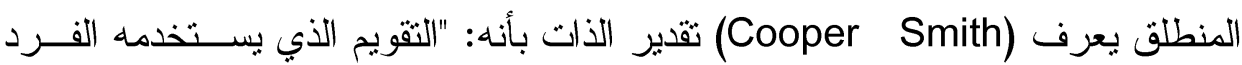

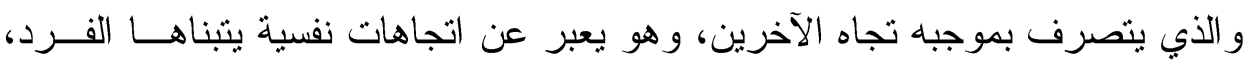

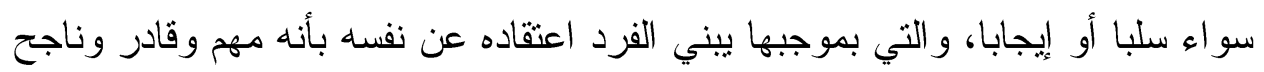
في حياته (كفافي، 9 . . ب).

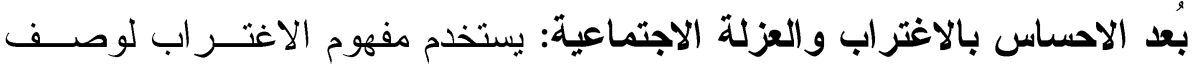

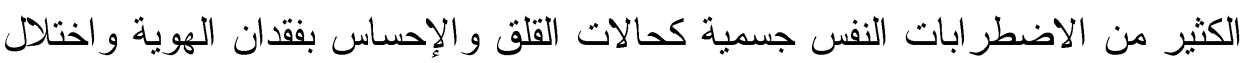
الشخصية و الشعور بالعجز و اللاجدوى و اللامبالاة و الإحساس بعـدم الثقــة و الثـــور 


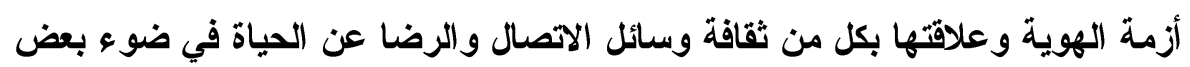

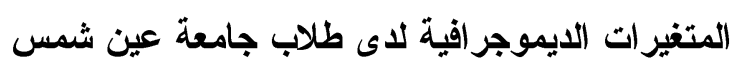

بالتنبؤ و أن الحياة تمضي على نحو لا إنساني و أنها عبث غير معقول يمضي بالإنســان

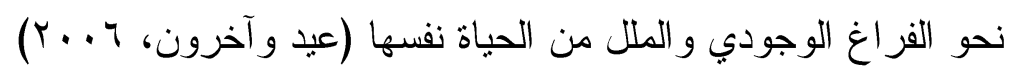

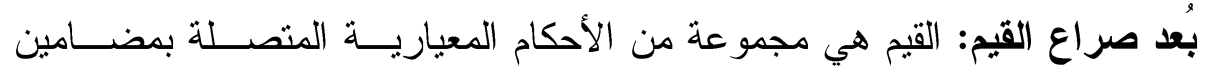

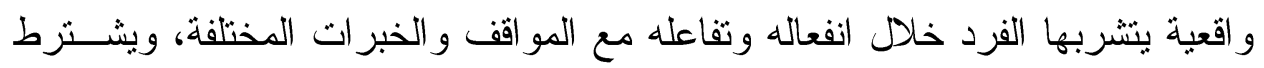
أن تتال هذه الأحكام قبو لا من جماعة اجتماعية معينة، حتى تجسد في ســـاقات الفــرد السلوكية و اللفظية أو اتجاهاته و اهتماماته (خالد، عبد الله، 9 . . ب).

ثانيا: ثقافة وسائل الاتصال (الثقافة الجماهيرية) 1 - مفهوم ثقافة وسائل الاتصال:

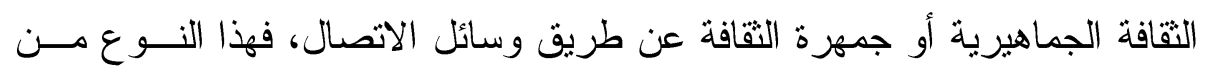

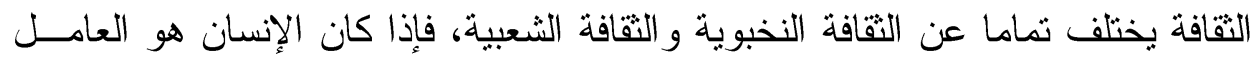
المحرك في الثقافة النخبوية وخاصة الشعبية؛ ففي الثقافة الجماهيرية تعنمد على التقانة

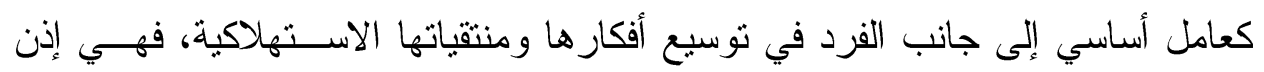

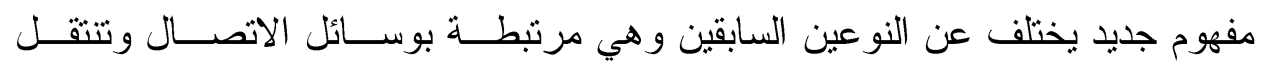
بو اسطتها، وهي تؤثر على أفر اد المجتمع بالتكر ار وطول الزمن، وبذللك فهي غالبا مــــا

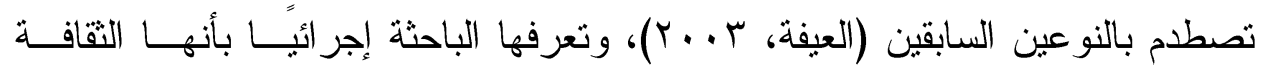

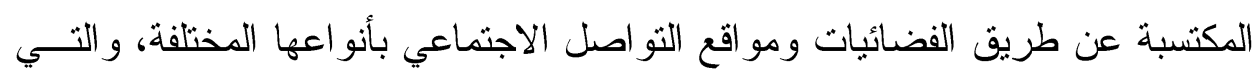

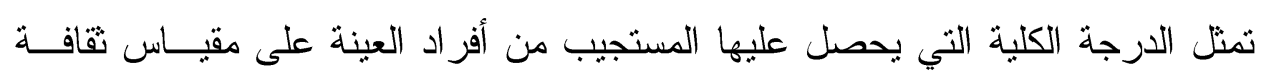
وسائل الاتصال المستخدم في هذه الدر اسة.

\section{r - الفضائيات}

وترجع الأهمية الثقافية للقنوات الفضائية إلى تطور ها التقني حيث أنها تحمل نوعــا

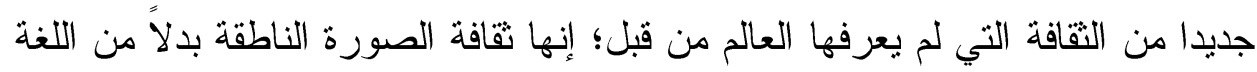

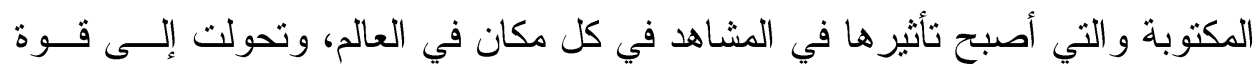

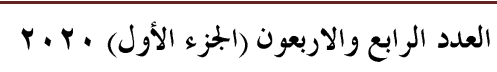
(94) مجلة كلية التربية- جامعة عين شمس 
هيمنة من خلال جعل المشاهدين أسرى جاذبية الصورة والصوت وبشكل يصعب معه

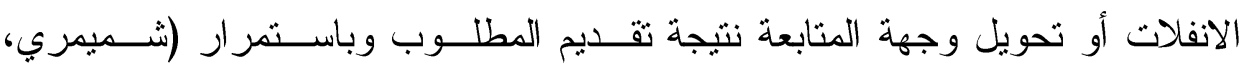
$\cdot(r \cdot)$.

\section{r - مواقع التو اصل الاجتماعي}

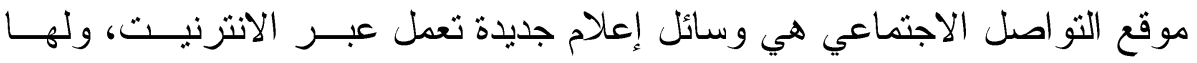

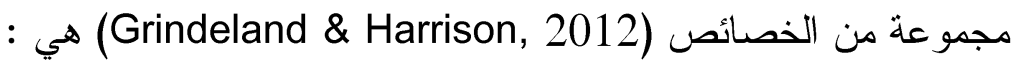
المشاركة: فهي تشجع على المساهمات وردود الفعل (التعليقات) مسن أبي مهـته، وتلغي الخط الفاصل بين وسائل الإعلام و المتلقين. الانفتاح: معظم شبكات نو اصل عبارة عن خدمات مفتوحة لردود الفعل و المشاركة

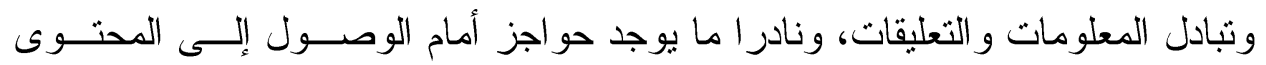
و الاستفادة منه، لأن حمايته بكلمة مرور أمر غير موجود نهائيا. المحادثة: تعتمد شبكات التو اصل الاجتماعي على المحادثة باتجاهين بعكس وسائل هرون لهان الإعلام التقليدية التي تعتمد مبدأ بث المعلومات ونشر ها باتجاه و احد لجميع المنلقين.

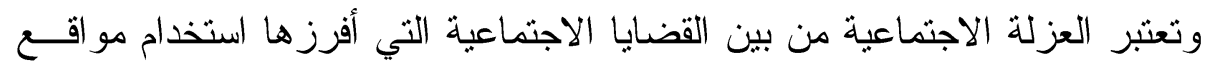

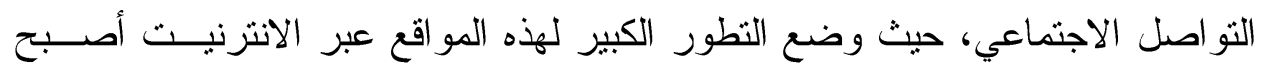
الأفر اد يتعلقون بشكل كبير بعلاقات التي ينشئنها عبر ها، يقضون وقتا كبير أمام الشاشة

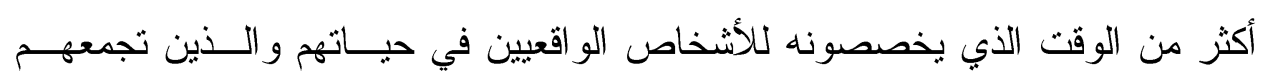
علاقات مختلفة، وهو ما يؤدي إلى العزلة الاجتماعية. ثالثًا: الرضا عن الحياة

$$
1 \text { - مفهوم الرضا عن الحياة: }
$$

هو حالة عقلية تثمثل في ثقييم شيء ما، وهذا المفهوم يشير إلى كل من الاســتمتاع

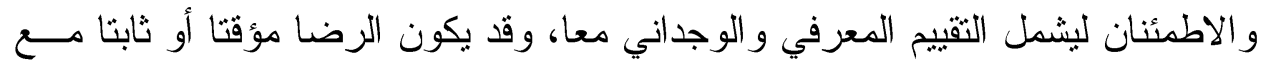

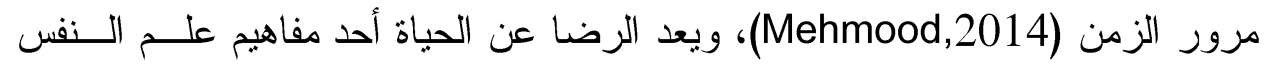


أزمة الهوية وعلاقتها بكل من ثقافة وسائل الاتصال والرضا عن الحياة في ضوء بعض

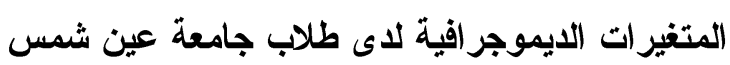

الإيجابي، وهو يمثل الثقيبم المعرفي العام للشخص (Gouveia,2009)، وهو شـعور

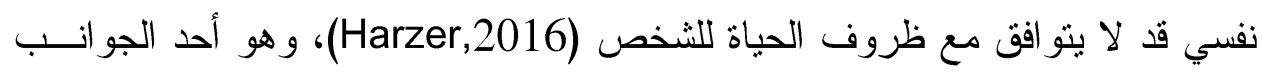

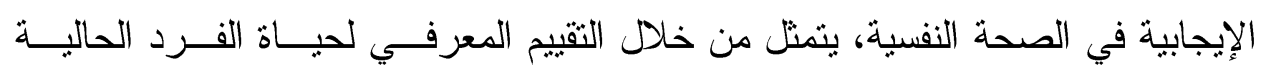
ووضع المعايير الداخلية لتقييم حياته الخاصة (Clench,2011) r - أبعاد الرضا عن الحياة

الســعادة: السعادة هي عنصر من عناصر الإشباع البيولوجي و الاجتماعي و النفسي

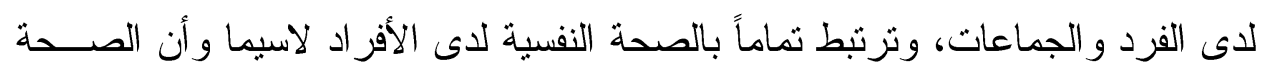
النفسية تتحقق بشعور الفرد بالسعادة والأمن و الاستقر ار النفسي. الرضا عن العلاقات الاجتماعية: إن الثخص الناجح في حياته و علاقاته الاجتماعبة

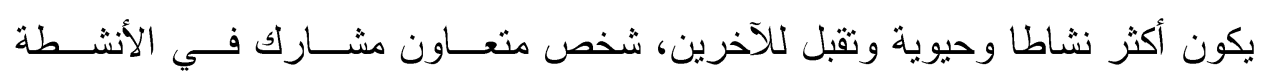
الاجنماعية.

التقدير الاجتماعي: أن الثقدير الاجتماعي له جانبان: الجانب الأول يأتي من خلال

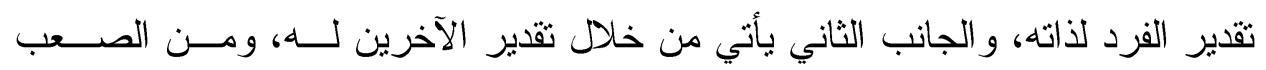

$$
\text { تحقيق أي جانب دون الآخر (المالكي، (1) ـ ب). }
$$

يرى فينهوفن أن المحددات المساهمة في الرضا عن الحياة ليست مفهومـــة تمامــــا

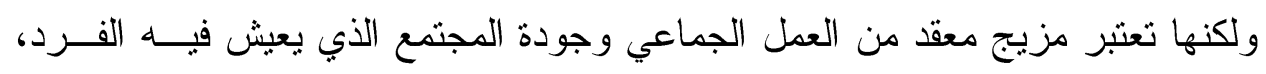

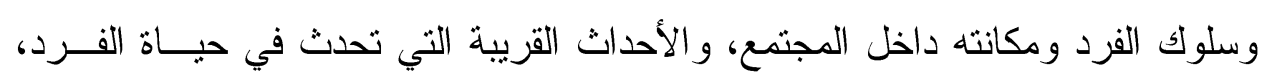

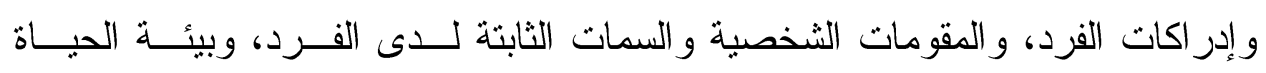
و الفرص المتاحة له . يعتمد الرضا عن الحباة على خبرات الفرد السابقة، والأحكام الداخلية و المعتقــدات

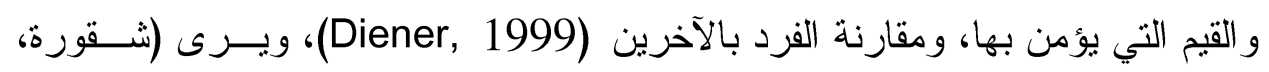




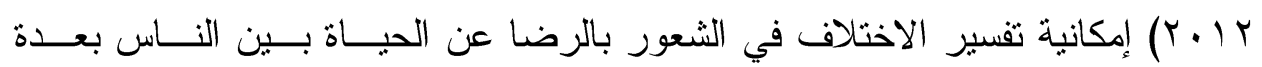

$$
\text { محددات أو عو امل منها: }
$$

1. تأثثر الظروف الموضو عية على الشعور بالرضا.

$$
\begin{aligned}
& \text { r. خبرة الأحداث السارة . } \\
& \text { r. الطموح و الإنجاز . } \\
& \text { ع. المقارنة مع الأخرين. }
\end{aligned}
$$

\section{فروض الار اسة}

الفرض الأول: ما مدى تأثثر ثقافة وسائل الاتصال الاجتماعي على أبعــاد أزمســة

$$
\text { الهوية لدى الثباب الجامعي. }
$$

الفرض الثاني: مدى نأثير الرضا عن الحياة على أبعاد أزمة الهوية.

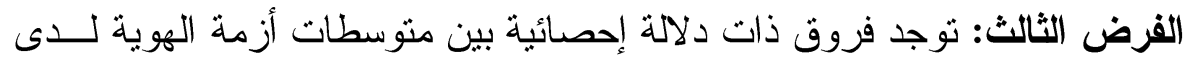
أفر اد عينة الدر اسة الفرض الرابع: توجد فروق ذات دلالة إحصائية بين متوسطات الرضا عن الحياة لاى أفر اد عينة الدر اسة تبعاً لبعض المتنغير ات دات الديمغر افية. الإجر اعات المنهجية للار استة لاعيزة

\section{أولا: هنهج الدراسة}

من أجل تحقيق أهداف الدراسة، قامت الباحثة باستخدام المنهج الوصفي التحليلي، و هو المنهج الذي يسعى إلى وصف الظواهر المدروسة، وتحليل البيانات المنعلقة بالظاهرة المدروسة، ودر اسة العلاقات بين مكونات هذه الظاهرة، حيث يتتــاول المنهج در اسة أحداث وظو اهر وممارسات قائمة ومتاحة للار اسة دون أن يتدخل الباحث في مجرياتها، وعلى الباحث أن يتفاعل معها بالوصف و التحليل، ويعتبر هذا المنهج طريقة في البحث عن الحاضر للإجابة عن تســاؤلات محـددة دون تدخل من الباحث في ضبط المتغير ات أو ادخال معالجات جديدة، و إنما يدرس ما

$$
\begin{aligned}
& \text { r.r. . العدد الرابع والاربعون (الجزء الأول) } \\
& \text { (97) } \\
& \text { مجلة كلية التربية- جامعة عين شمس }
\end{aligned}
$$


أزمة الهوية وعلاقتها بكل من ثقافة وسائل الاتصال والرضا عن الحياة في ضوء بعض

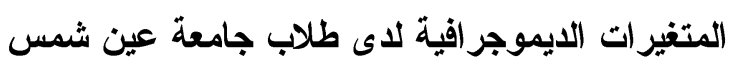

هو موجود أو كائن (ملحم، . . . Y)'، لذا فإن الباحثة اعتمدت على هذا المـــهج للوصول إلى المعرفة الدقيقة و التقصيلية حول مشكلة البحث، ولتحقيـق تصـــور

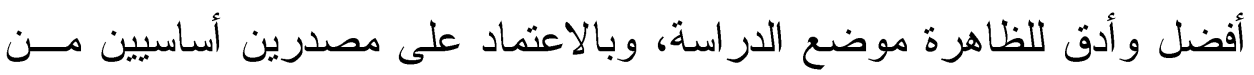
مصادر جمع البيانات وهي: أ - المصادر الثانوية: حيث اتجهت الباحثة في معالجة الإطار النظري للار اسة إلى مصادر البيانات الثانوية والتي تتمثل في الكتب و المر اجع العربية و الأجنبية ذات العلاقة، والدوريات و المقالات و التقارير ، و الأبحاث و الدر اسات السابقة التي تناولت موضوع الدر اسة، و البحث و المطالعة في مواقع الإنترنت المختلفة. ب - المصادر الأولية: وتتمثل في جمع البيانات الأولية ميدانياً، وذلك من خلال

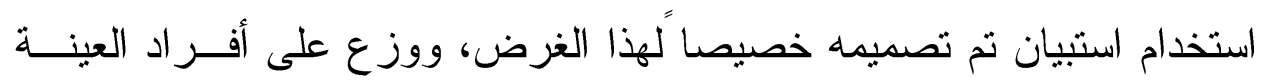
لجمع البيانات المطلوبة.

\section{ثانيًا: هيدان الدراسة لهم}

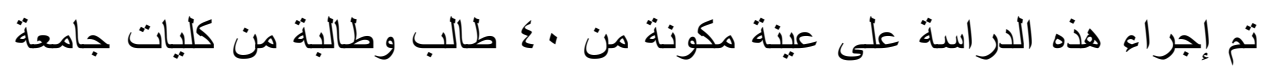
عين شمس. وقد تألفت عينة الاراسة من: أ - العينة الاستطلاعية: أجريت هذه الدر اسة الاستطلاعية على عينة مكونة من

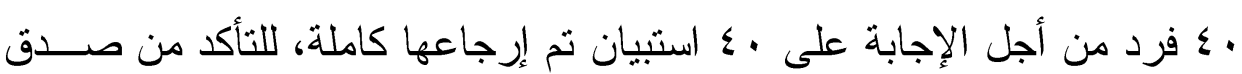
وثبات الاختبار المقياس.

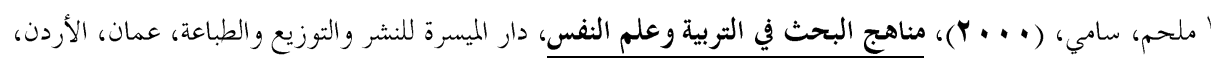
D 
ب - أداة القياس: اعتمدنا في در استتا الحالية على ثلاث مقياس وهم، مقيــاس ازمة الهوية، ومقياس ثقافة وسائل الاتصال، ومقياس الرضا عن الحياة. ج -الخصائص السيكومترية لأداة القياس: للتأكد من أداة الدر اسة المستخدمة تسنطيع أن تقيس ما وضعت من أجله لتقيســه يجب قياس الخصائص السيكومترية لهذه الأداة و هذه الخصــائص تتمثـلـل فـي الصدق و الثبات وسنتطرق إلى كيفية حساب كل خاصية من هاتين الخاصيتين. ه - العينة الفعلية: تكون عينة الدراسة من . ع طالب وطالبة مقسـمين إلـى

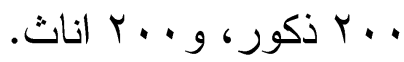

\section{ثالثًا: أدوات الدراسة}

استعانت الباحثة بعدة أدوات، بهدف التوصل إلى إجابات لتســاؤلات الدراســة، و التحقق من فروضها، وكانت هذه الأدوات عبارة عن: I - البيانات الشخصية: ونشمل النوع، ونوع السكن، ونوع الكليــة، و العدــر ، و المستوى الاقتصادي.

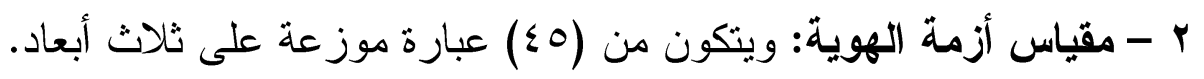
r - مقياس ثقافة وسائل الاتصال: ويتكون من (Y0) عبارة. ع - مقياس الرضا عن الحياة: ويتكون من ( •ع) عبارة موزعة خمسة أبعاد. وقامت الباحثة بالتأكد من الخصائص السيكومترية ومقياس أزمة الهوية، ولمقياس

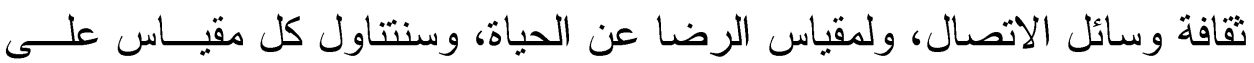
حدة. 
أزمة الهوية وعلاقتها بكل من ثقافة وسائل الاتصال والرضا عن الحياة في ضوء بعض الرض

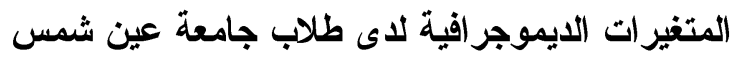

\section{نتائج الار اسة}

أولاً: مستوي درجة الرضا عن العباة:

جدول (r) آراء عينة الاراسة في كل بعد من أبعاد الرضا عن الحياة مرنبة تنازلياً

$(\varepsilon \ldots=0)$

\begin{tabular}{|c|c|c|c|c|c|}
\hline 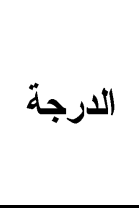 & المئوي المرسط & المعياري الافر & المتوسط & ترتيب & أبعاد الرضا عن الحياة \\
\hline مرتفعة & $\% \wedge \varepsilon . \varepsilon$. & .071 & Y.OH & 1 & 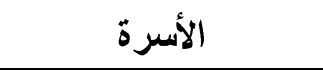 \\
\hline مرتفعة & $\% \vee 9.0 \mathrm{~V}$ & $\cdot . \leqslant \wedge)$ & Y.rNV & r & 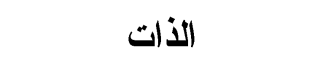 \\
\hline مرتفعة & 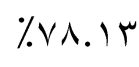 &. .791 & $r . r \leq \varepsilon$ & r & الأصدقاء \\
\hline متوسطة & \%YY.VV & $\cdot . \leqslant \vee \wedge$ & r.ı & $\varepsilon$ & بيئة الحياة \\
\hline متوسطة & \%YT.YV & .719 & r.171 & 0 & الجامعة \\
\hline متوسطة & $\% \vee \vee .1$. & سדצ. & (M.M & \multicolumn{2}{|c|}{ الدرجة الكلية لأبعاد الرضا عن الحياة } \\
\hline
\end{tabular}

يظهر الجدول رقم (r) المتوسطات الحسابية والانحر افات المعياريــة لاســتجابات

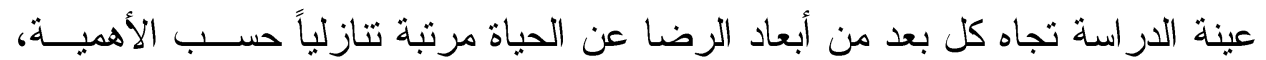

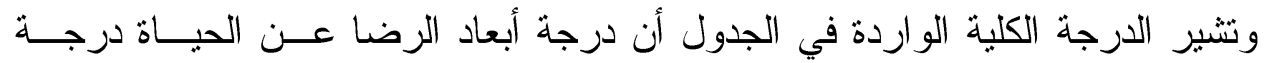

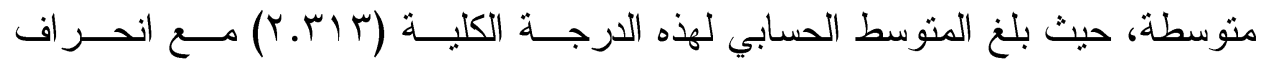

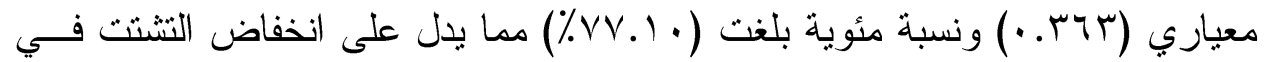
آر اء عينة الدر اسة تجاه أبعاد الرضا عن الحباة، وقد جاءت ثلاث أبعاد بدرجة مرتفعة،

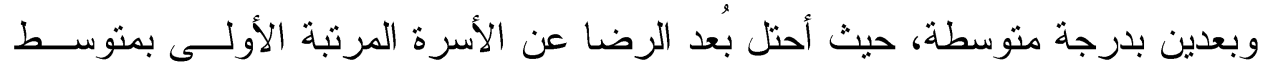

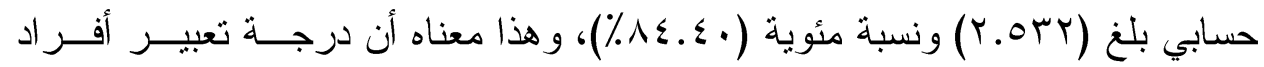

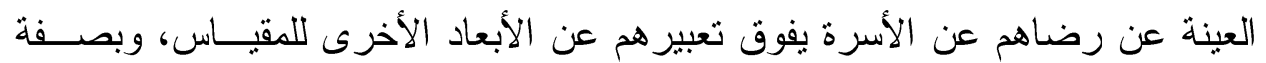

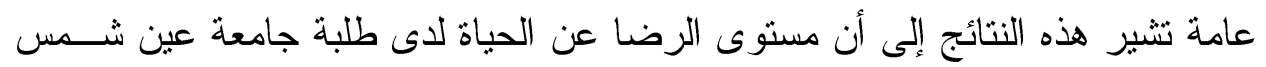


كان فوق المتوسط حيث بلغت النسبة المئوية لإجمالي أبعاد مقياس الرضا عن الحيـاة

$$
\text { . }(\% \vee \vee .) \cdot)
$$

ثانباً: أهم ملامتح أزمة النهوية:

جدول (ء) آراء عينة الاراسة في كل بعد من أبعاد أزمة الهوية مرتبة تنازلياً

$$
(\varepsilon \ldots \text { ( ن }
$$

\begin{tabular}{|c|c|c|c|c|c|}
\hline الدرجة & المئوي المرسط & الالمعراف & المتوسط & ترأهميب & أبعاد أزمة الهوية \\
\hline متوسطة & $\% \vee 0.0$. & $.0 Y$. & Y.YTO & 1 & الإحساس بالاغتر اب \\
\hline متوسطة & $\% \vee \leqslant . \wedge$. & $.0 \mathrm{NV}$ & Y. Y $\leq \varepsilon$ & r & صر اع القيم \\
\hline متوسطة & \%YY.s. & $. \leqslant 0 \leqslant$ & r.IVY & $r$ & ضعف تقدير الذات \\
\hline متوسطة & $\%$ \%r.AT &. rqV & Y.YIT & \multicolumn{2}{|c|}{ اللارجة الكلية لأبعاد أزمة الهوية } \\
\hline
\end{tabular}

يظهر الجدول رقم (ع) المتوسطات الحسابية و الانحر افات المعباريــة لاســتجابات

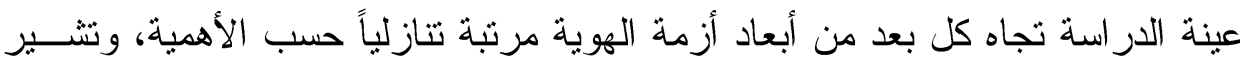

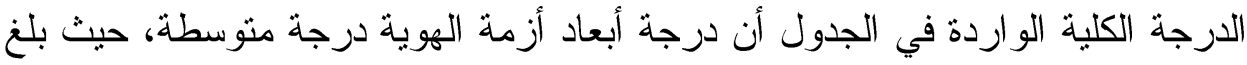

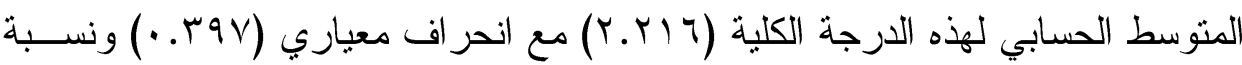

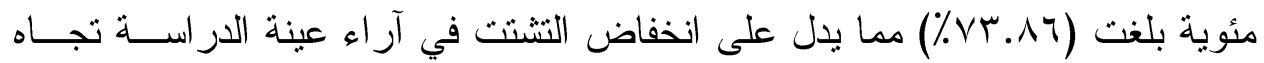

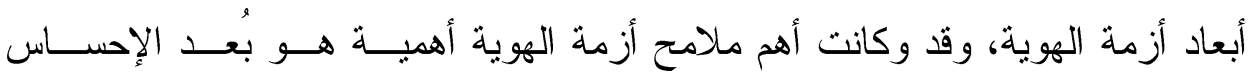

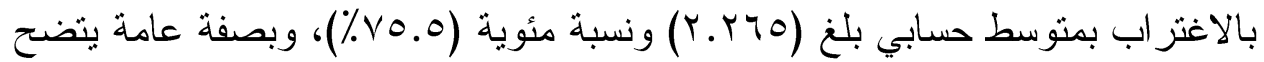

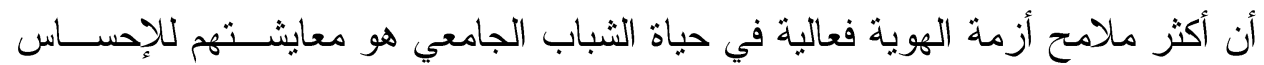
بالاغتر اب، ولعل هذا الاغتر اب يعود إلى تعدد المتغير ات المعاصرة.

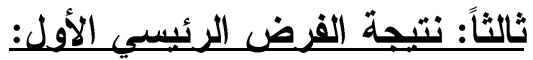
توجد علاقة أثر ذات دلالة إحصائية لثقافة وسائل الاتصال على أبعاد أزمة الهوية

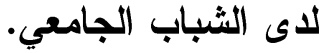


أزمة الهوية وعلاقتها بكل من ثقافة وسائل الاتصال والرضا عن الحياة في ضوء بعض

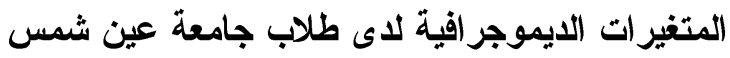

\begin{tabular}{|c|c|c|c|c|c|c|c|c|c|}
\hline \multicolumn{10}{|c|}{ أبعاد أزمة الهوية } \\
\hline مستوية الدلالة & المحسوبة & \multicolumn{2}{|c|}{ الانحدار } & \multicolumn{2}{|c|}{ درجات } & مستوي & المحسوبة & التحديد معامل & التابعير \\
\hline \multirow{3}{*}{$\cdot, \cdot$} & \multirow{3}{*}{$1 \cdot, \vee \wedge$} & $\vee, \wedge \wedge r$ & الثابت & 1 & الانحدار & \multirow{3}{*}{$\cdot, \ldots$} & \multirow{3}{*}{$117, r r$} & \multirow{3}{*}{ • } & \multirow{3}{*}{ ضقدف } \\
\hline & & \multirow{2}{*}{$\cdot, r 01$} & \multirow{2}{*}{ الاتصال } & $r 9 \Lambda$ & البو اقي & & & & \\
\hline & & & & rqq & المجموع & & & & \\
\hline \multirow{3}{*}{$\cdot, \cdots$} & \multirow{3}{*}{$|7, r|$} & $r, 907$ & الثابت & 1 & الانحدار & \multirow{3}{*}{$\cdot, \cdots$} & \multirow{3}{*}{ זษ } & \multirow{3}{*}{$\cdot, \varepsilon \cdot 1$} & \multirow{3}{*}{ بالإ غتر ابـ } \\
\hline & & \multirow[b]{2}{*}{$\cdot, 119$} & \multirow{2}{*}{ الاتصال } & $r 91$ & البو اقي & & & & \\
\hline & & & & एवq & المجموع & & & & \\
\hline \multirow{3}{*}{$\cdot, \cdot$} & \multirow{3}{*}{ Ir,qr } & $1,9 \leq$ & الثنابت & 1 & الانحدار & \multirow{3}{*}{$\cdot, \cdots$} & \multirow{3}{*}{$17 V, Y 4$} & \multirow{3}{*}{ - } & \multirow{3}{*}{ صراع } \\
\hline & & \multirow[b]{2}{*}{$\cdot$, roג } & \multirow{2}{*}{ الاتصال } & $r 91$ & البو اقي & & & & \\
\hline & & & & rqq & المجموع & & & & \\
\hline
\end{tabular}

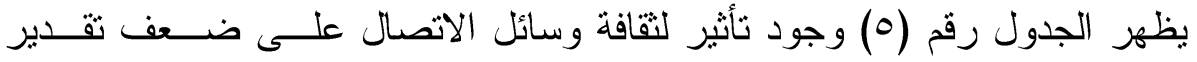

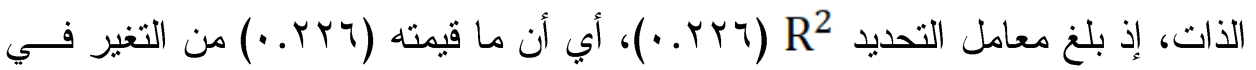

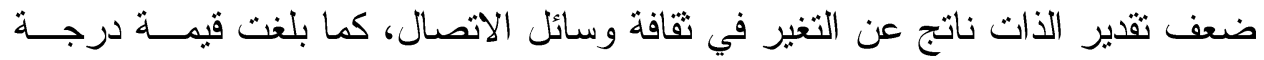

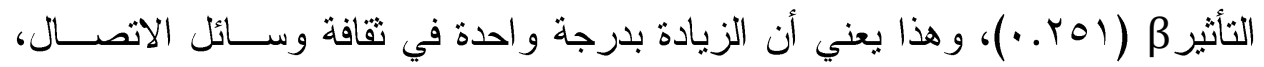

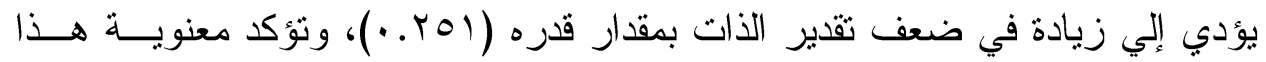

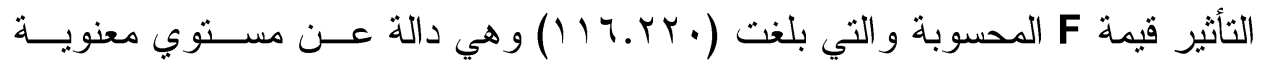

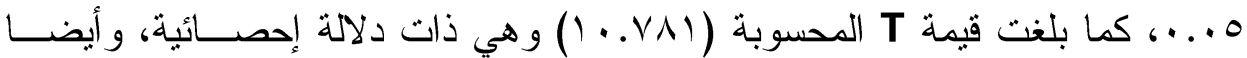

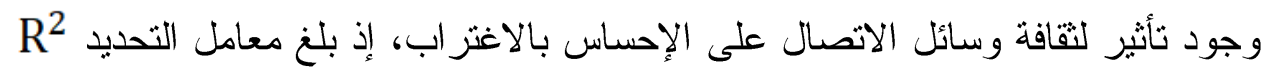

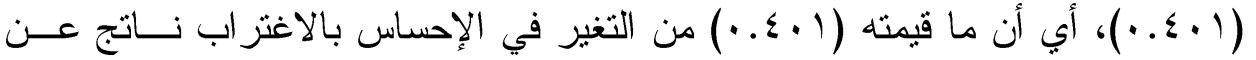

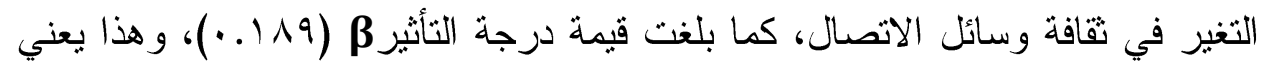

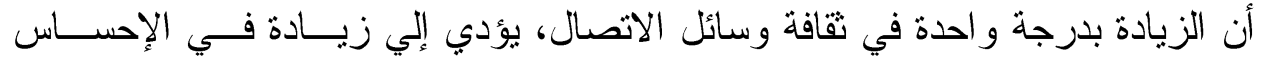




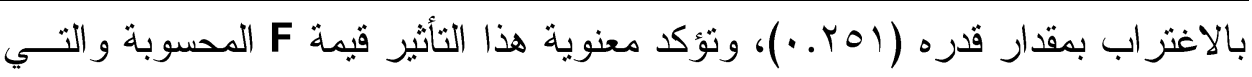

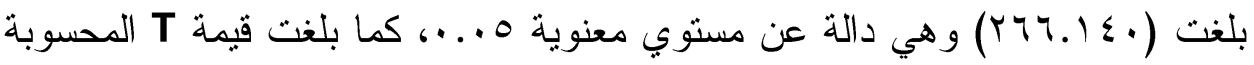

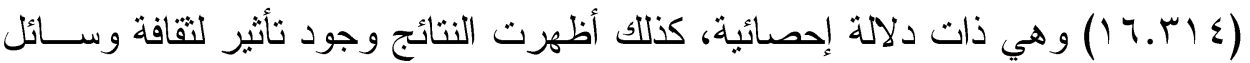

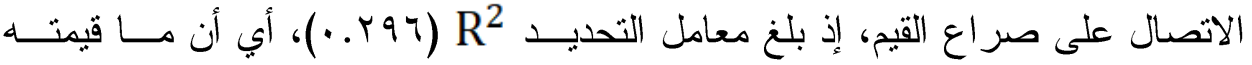

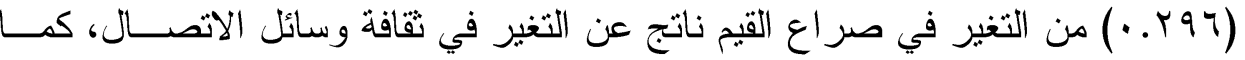

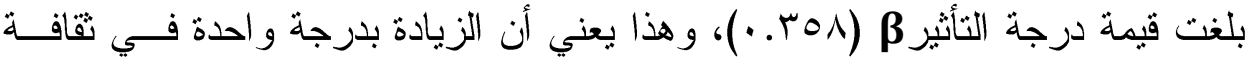

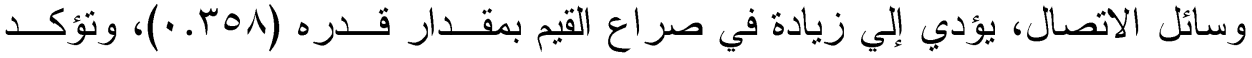

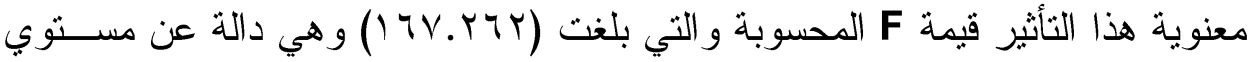

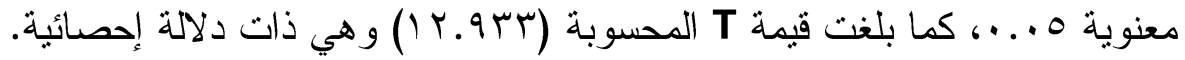
رابعاً: نتبجة الفرض الرئبسي الثاني: توجد علاقة أثر ذات دلالة إحصائية للرضا عن الحياة على أبعاد أزمة الهوية لاى الثباب الجامعي. جدول (†) نتائج الآحدار الخطي البسيط لتأثير الرضا عن الحياة على أبعاد أزمة الهوية

\begin{tabular}{|c|c|c|c|c|c|c|c|c|c|}
\hline الدسلةدّ & المحسوبة & \multicolumn{2}{|c|}{ الانحدار } & \multicolumn{2}{|c|}{ درجات } & الدسلاة & المحسوبة & $\begin{array}{c}\text { التحديدمل } \\
\text { R }^{2}\end{array}$ & التنابع \\
\hline \multirow{3}{*}{$\cdot, \ldots$} & \multirow{3}{*}{$0, \lambda 7_{-}$} & $r q, .09$ & الثابت & 1 & الانحدار & \multirow{3}{*}{$\cdot, \ldots$} & \multirow{3}{*}{$\Gamma \leqslant, \varepsilon 17$} & \multirow{3}{*}{$\cdot, \cdot \wedge}$. & \multirow{3}{*}{ تقاتير } \\
\hline & & \multirow{2}{*}{ -, $710_{-}$} & \multirow{2}{*}{ الرن الرضا } & r9ג & البو اقي & & & & \\
\hline & & & & r99 & الدجموع & & & & \\
\hline \multirow{3}{*}{$\cdot, \ldots$} & \multirow{3}{*}{$1,01}$. & 04,070 & الثابت الثقار & 1 & الانحدار & \multirow{3}{*}{$\cdot, \ldots$} & \multirow{3}{*}{$V Y, \Sigma \neg \Lambda$} & \multirow{3}{*}{ - $10 \leqslant$} & \multirow{3}{*}{ بالإغتراب } \\
\hline & & \multirow{2}{*}{ - $94 \cdot-$} & \multirow{2}{*}{ الرعناة } & $r 91$ & البواقي & & & & \\
\hline & & & & एव१ & الدجموع & & & & \\
\hline \multirow{3}{*}{$\cdot, \cdot$} & \multirow{3}{*}{$9,19}$. & $V \psi, \wedge 9 \wedge$ & الثابت & 1 & الانحدار & \multirow{3}{*}{$\cdot, \cdots$} & \multirow{3}{*}{$\Lambda \varepsilon, 009$} & \multirow{3}{*}{ - IVo } & \multirow{3}{*}{ صراع } \\
\hline & & \multirow{2}{*}{ - , А९৭ } & \multirow{2}{*}{ الرعن الرضاة } & r91 & البو اقي & & & & \\
\hline & & & & r99 & الدجموع & & & & \\
\hline
\end{tabular}


أزمة الهوية وعلاقتها بكل من ثقافة وسائل الاتصال والرضا عن الحياة في ضوء بعض

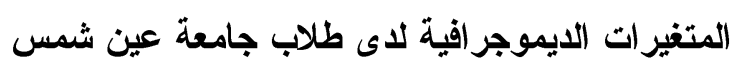

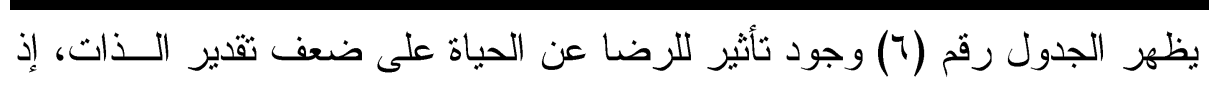

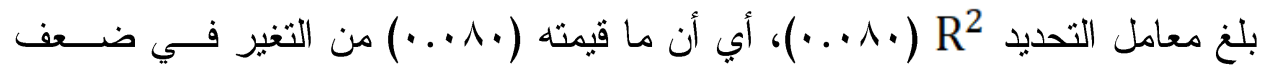

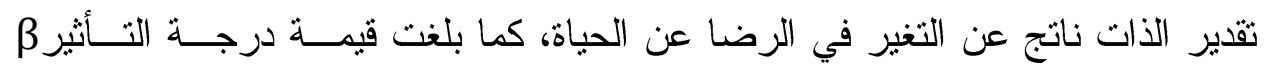

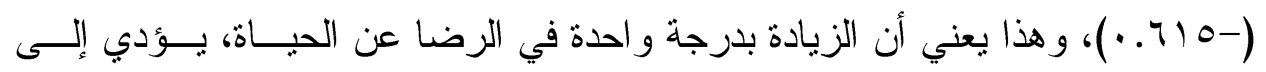

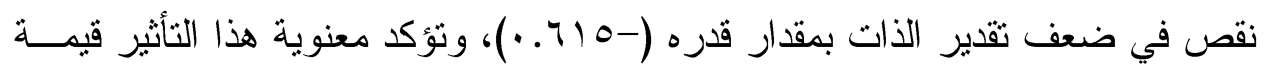

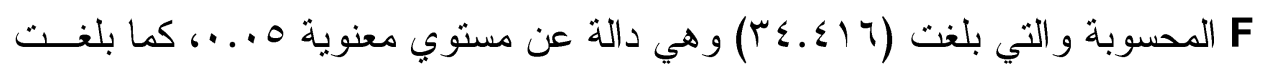

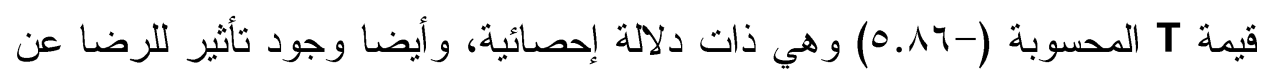

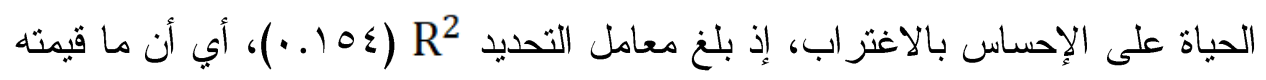

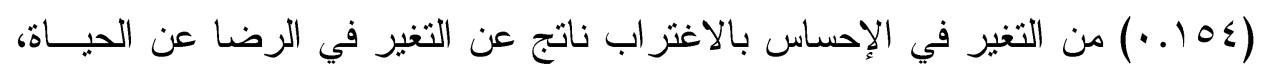

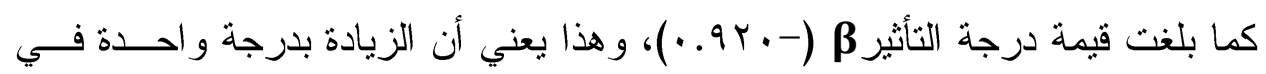

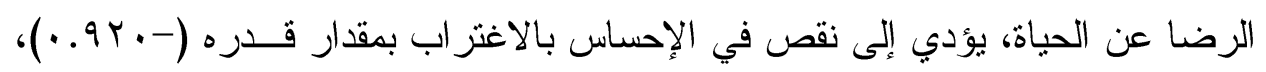

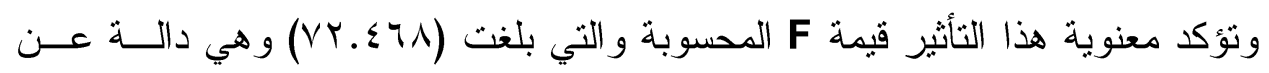

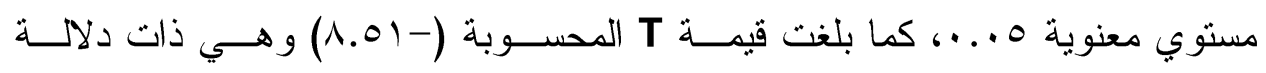
إحصائية، كذلك أظهرت النتائج وجود تأثير للرضا عن الحياة على صر اع القيم، إذ بلغ معامل التحديد

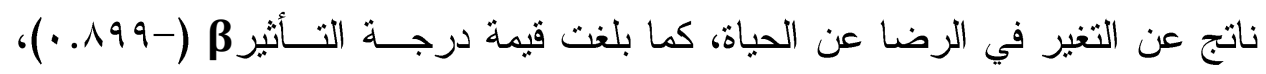

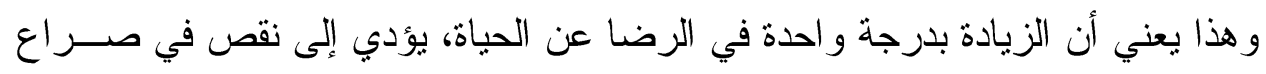

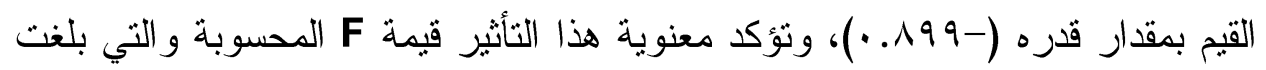

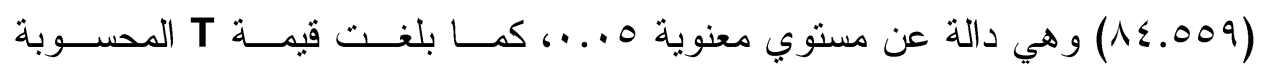
(9-19-19) وهي ذات دلالة إحصائية.

r.r. العدد الرابع والاربعون (الجزء الأول)

(104)

مجلة كلية التربية- جامعة عين شمس 
أ/بسنت عدلي حسن محمد

خامسا: نتيجة الفرض الرئيسي الثالث:

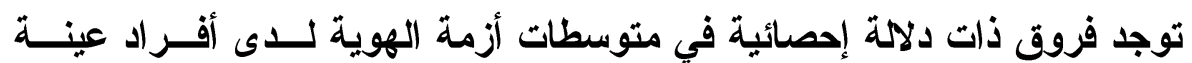

الار اسة تبعًا لبعض المتغيرات الديمغرافية.

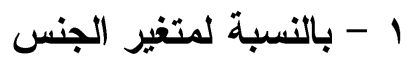

جدول (V) اختبار T-Test بوضح الفروق في أبعاد أزمة الهوية تبعا لمتغير الجنس.

\begin{tabular}{|c|c|c|c|c|c|c|c|}
\hline \multirow{2}{*}{ الفروق } & \multirow{2}{*}{ دلالة } & \multirow{2}{*}{ قيمة t } & \multicolumn{2}{|c|}{ الاناث ن = . . r r } & \multicolumn{2}{|c|}{ الأكور ن = . . r r } & \multirow{2}{*}{ أبعاد أزمة } \\
\hline & & & $\varepsilon$ & م & $\varepsilon$ & م & \\
\hline لالا توجد & T.VI & $\cdot . r \cdot 1$ & V.VII & Tr.TA & $v .001$ & Tr.91 & بالإغتر اب \\
\hline لالالة & $\because \vee \wedge \varepsilon$ & .rvo & $9.1 \leq 4$ & r..$\varepsilon$ & $9 . . \leqslant 4$ & TI. & صر اع القيم. \\
\hline لالا توجد &. .109 &. $.1 \mathrm{\gamma}$ & $V . \varepsilon \cdot r$ & $r . . r q$ & V.rrq & $r . \leqslant r$ & ضنعف تقدير \\
\hline لالا توجد & . vor &. .417 & $19 . \leqslant \leqslant r$ & $90 . r V$ & $19.10 \mathrm{~V}$ & 90.91 & إجمالي أزمة \\
\hline
\end{tabular}

أظهرت نتائج الجدول رقم (V) عدم وجود فروق بين الذكور و الإناث فـي أبعـاد

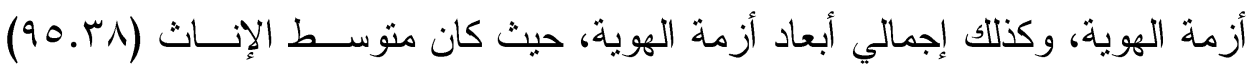

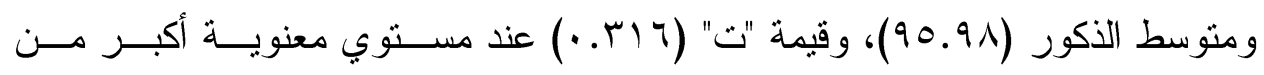

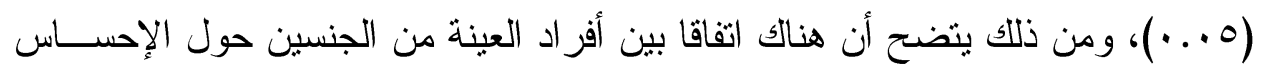
بالاغتر اب، وصر اع القيم، وضعف تقدير الذات، وأن كلا الجنسين لديهم إحساس بأزمة الهوية في الأبعاد الثلاثة دون تميز جنس عن الآخر. 
أزمة الهوية وعلاقتها بكل من ثقافة وسائل الاتصال والرضا عن الحياة في ضوء بعض

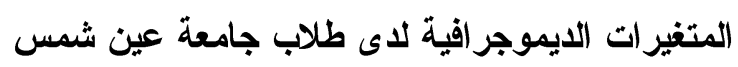

$$
\text { r }
$$

جدول (^) اختبار T-Test يوضح الفروق في أبعاد أزمة الهوية تبعا لمتغير نوع السكن

\begin{tabular}{|c|c|c|c|c|c|c|c|}
\hline \multirow{2}{*}{ اتجاه الفروق } & \multirow{2}{*}{ دلامة د د } & \multirow{2}{*}{ قيمة } & \multicolumn{2}{|c|}{ 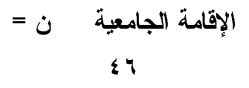 } & \multicolumn{2}{|c|}{ المنزل ن = ع هب } & \multirow{2}{*}{ أبعاد أزمة الهوية } \\
\hline & & & $\varepsilon$ & s & $\varepsilon$ & م & \\
\hline لا توجد دلالة & $\cdot .9 \mathrm{VV}$ & .r. & V.YAq & Tr.AT & V.TVo & Tr.Vq & الإحساس بالاغتر اب \\
\hline لا توجد دلالة & $\cdot . \leqslant 1 \leqslant$ & $\cdot . \Lambda \mathrm{V}$ & איד 1. 1 & 1.0. & $9.1 \leq 7$ & ד. & صراع القيم \\
\hline لا توجد دلالة &. $.1 \vee q$ & $.10 r$ & $V . \cdot V r$ & M.r. & V.ror & T.M & ضعف تقدير الأات \\
\hline لا توجد دلالة & .748 & ו & IV.ON & $9 \leq . \lambda 1$ & 19.011 & $90.1 Y$ & إجمالي أزمة الهوية \\
\hline
\end{tabular}

أظهرت نتائج الجدول رقم (^) عدم وجود فروق بين المنزل و الإقامة الجامعية في لهابه

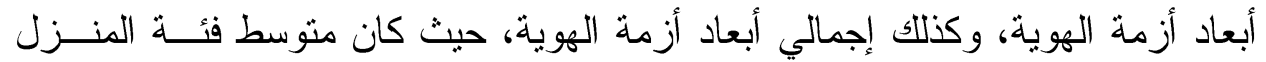

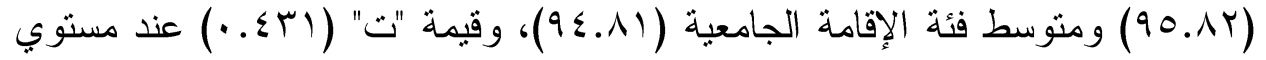
معنوية أكبر من (0. . )، ومما سبق يتضح لنا عدم تحقق الفرض الرئيسي الثالث التي رأي

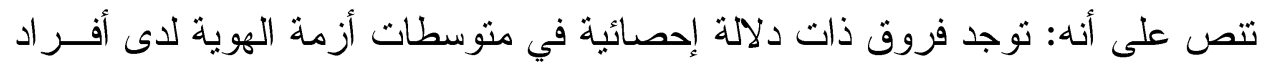

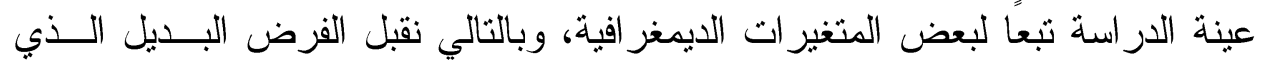

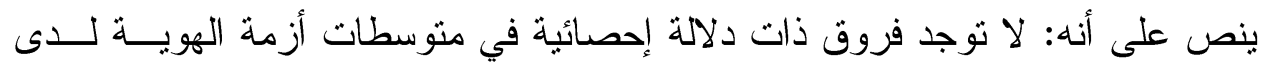
أفر اد عينة الدر اسة تبعًا لبعض المتغير ات ات الديمغر افية.

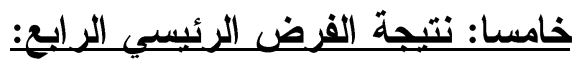
توجد فروق ذات دلالة إحصائية في منوسطات الرضا عن الحياة لاى أفراد عينة الار اسة تبعًا لبعض المتغير ات الايمغر افية. | بالنسبة لمتغير الجنس 
أ/بسنت عدلي حسن محمد

جدول (9) اختبار T-Test يوضع الفروق في الرضا عن الحياة تبعا لمتغير الجنس

\begin{tabular}{|c|c|c|c|c|c|c|c|}
\hline \multirow{2}{*}{ اتجاه الفروق } & \multirow{2}{*}{ دلامة د د } & \multirow{2}{*}{ قيمة t } & \multicolumn{2}{|c|}{ الآاث ن = . . r r } & \multicolumn{2}{|c|}{ الأكور ن = . . r r } & \multirow{2}{*}{ عن أبعاد الرضا } \\
\hline & & & $\varepsilon$ & a & $\varepsilon$ & م & \\
\hline لصالح الاناث & $\cdots$ & $0.70 \mathrm{~V}$ & T.YYE & $1 \wedge . \wedge$. & $\varepsilon . r+q$ & 17.74 & الأسرة \\
\hline لصالح الاناث & $\cdots+1$ & r.A9 & 7.090 & TE.MT & $0 .+r V$ & Yr.. E & الاصدقاء \\
\hline لصالح الاناث & $\cdots$ & r.ro. & $\leq . \wedge \uparrow \wedge$ & $11.1 \mathrm{~V}$ & $\varepsilon .9 Y T$ & 17.04 & الجامعة \\
\hline لصالح الاناث & $\cdots$ & $T .|Y|$ & r.rvq & 11.97 & S.MYI & 17.74 & بيئة الحياة \\
\hline لصالح الاناث & $\ldots$ & $7 . .9$. & r.ror & $1 \wedge . \wedge 7$ & S.YYY & 17.07 & الذات \\
\hline لصالح الاناث & $\cdots$ & $\lambda . \mid r \lambda$ & $11 . r 01$ & $9 \wedge . \leqslant 1$ & K. & $\wedge \wedge . r \varepsilon$ & الجمالي أبعاد \\
\hline
\end{tabular}

أظهرت نتائج الجدول رقم (9) وجود فروق بين الذكور و الإناث في جمبــع أبعـاد

الرضا عن الحياة، وكذلك في أجمالي أبعاد الرضا عن الحياة، حيث كان متوسط الإناث

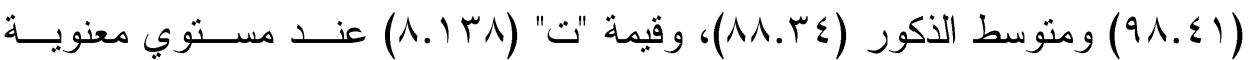

(0 . . •)، و هي بذلك تكون دالة إحصائياً، ومن هنا نستطيع القول بأنه توجد فروق بين الأكور و الإناث في أجمالي أبعاد الرضا عن الحياة لصالح الإناث، حيــث أن منوسـط الإناث قد جاء أكبر من منوسط الذكور.

جدول ( • 1) اختبار T-Test يوضح الفروق في أبعاد الرضا عن الحياة تبعا لمتغير نوع السكن

\begin{tabular}{|c|c|c|c|c|c|c|c|}
\hline \multirow{2}{*}{ الفروق الجاه } & \multirow{2}{*}{ دلامة Tستوي } & \multirow[t]{2}{*}{ قيمة t } & \multicolumn{2}{|c|}{ الإقامة الجامعية } & \multicolumn{2}{|c|}{ المنزل ن = ؟ هـ } & \multirow{2}{*}{ أبعاد الرضا عن } \\
\hline & & & $\varepsilon$ & a & $\varepsilon$ & 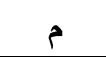 & \\
\hline غير دالة &. $.71 \varepsilon$ & $.0 . \varepsilon$ & ع ז.0T & $1 \wedge . \ldots$ & 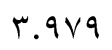 & 18.79 & الأسرة \\
\hline غير دالة &. .177 & $1 . \mathrm{TAN}$ & $0.00 \leqslant$ & س & $7 .+10$ & r... & الاصدقاء \\
\hline غير دالة & .910 & $\cdot . \varepsilon \cdot 7$ & $\varepsilon .9 \vee V$ & IV..V & $\{.971$ & $\mid V . r \Lambda$ & الجامعة \\
\hline غير دالة &. $.9 \varepsilon$ & $1.7 \vee \wedge$ & $\varepsilon . v_{0}$ & $1 \Lambda . V Y$ & $r .9 V T$ & $1 \mathrm{~V} .7 \mathrm{~V}$ & بيئة الحياة \\
\hline
\end{tabular}

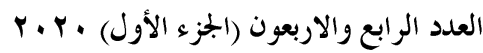

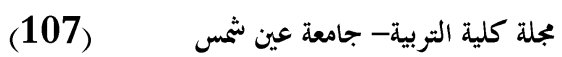




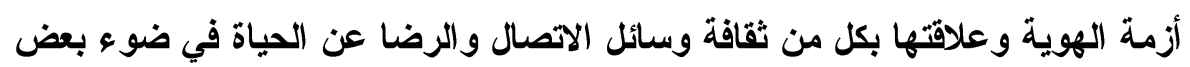

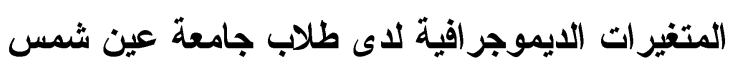

\begin{tabular}{|c|c|c|c|c|c|c|c|}
\hline غير دالة & . TrV & 1.111 & r.orv & IN.YY & r.qAץ & IV.TE & الذات \\
\hline غير دالة & . . & צחז.. & $1 \% .114$ & $9 \leqslant . V \leqslant$ & דא. & Qr.r. & إجمالي أبعاد الرضا \\
\hline
\end{tabular}

أظهرث نتائج الجدول رقم (• (1) عدم وجود فروق بين المنزل و الإقامة الجامعيــة

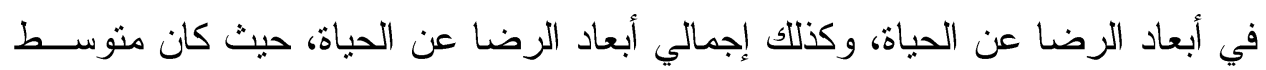

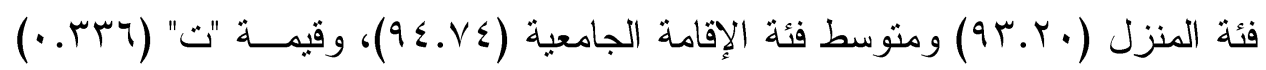

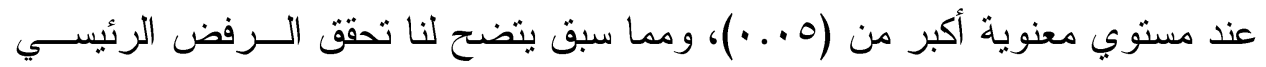

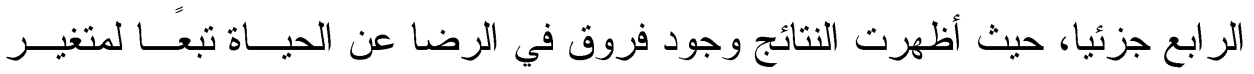
الجنس لصالح الإناث، عدم وجود فروق في الرضا عن الحياة تبعاً لمتغير السكن من هنا توصلت الاراسة لعدة نتائج هامة هي:

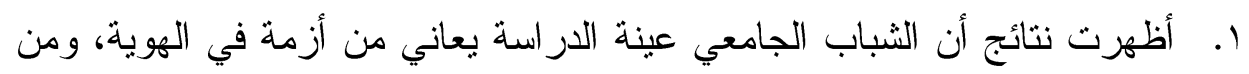
أهم ملامح تللك الأزمة: الإحساس بالعزلة والاغتر اب عــن المجتمــع، ومعانــاة

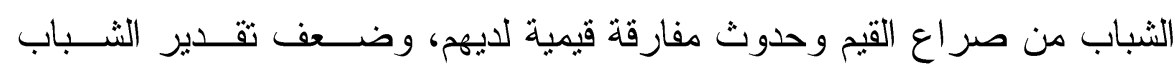

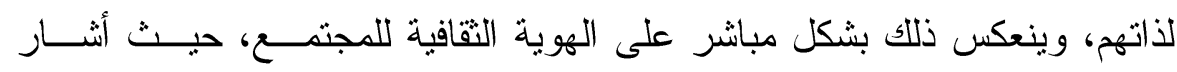
(Miville, 2000) وكذلك وجود أزمة في الهوية الثقافية ينعكس بشكل مباشر على الهويـــة الذاتيــة

$$
\text { للفرد. }
$$

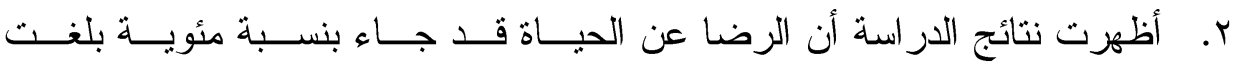

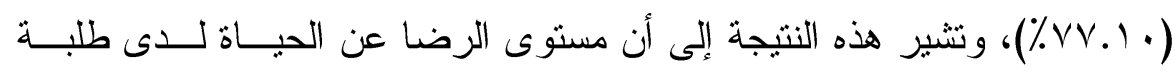

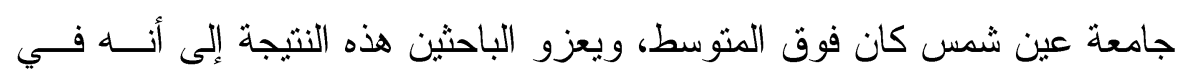

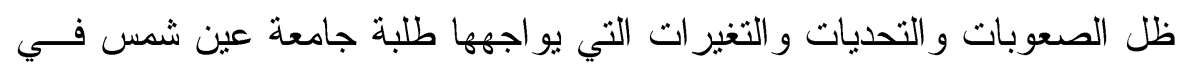

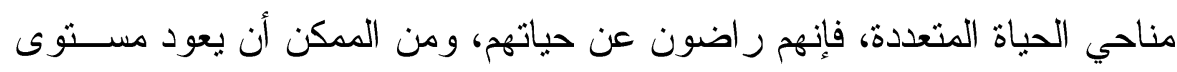

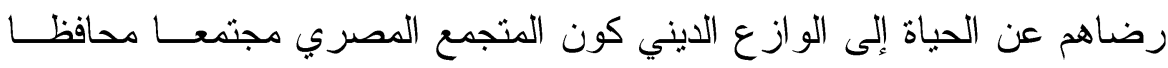


ومتمسكا بالقيم الاسلامية، بالإضـافة إلى تأقلمهم مع الظروف الحياتبـــة المحبطـــة

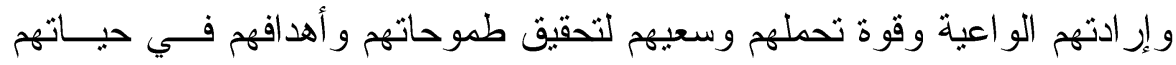

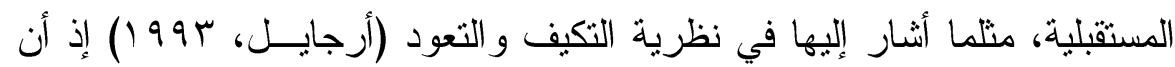

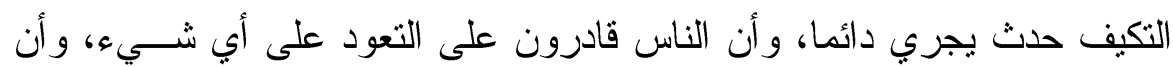

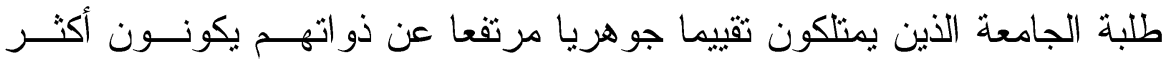

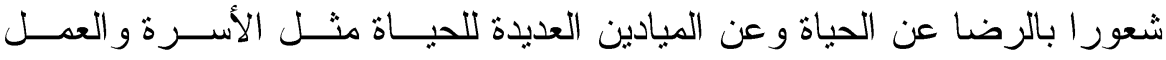
و الدر اسة، كما أثنار إلى ذلك في نظرية الثقييم (Judge, 1997).

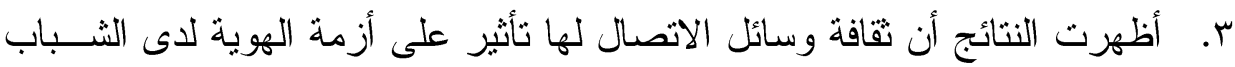

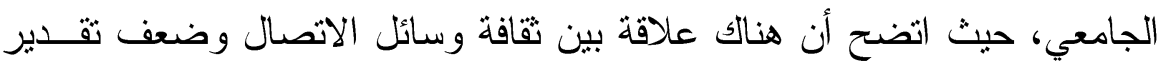

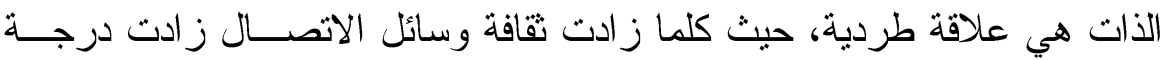

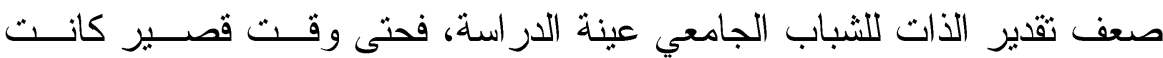
عو امل انخفاض تقدير الذات مفهومة بشكل جيد، لكـن مـــع طفــرة التو اصـــل الاجتماعي الإككتروني خلال السنوات القليلة الماضية برزت وســائل التو اصـلـل

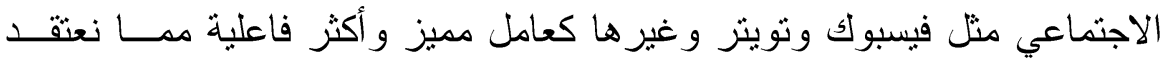

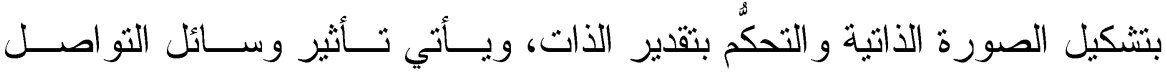
الاجتماعي على تقدير الذات من خلال المقارنات التي يقـوم بهــــا المســتخدمون

$$
\text { بشكل أساسي (Vogel, 2014). }
$$

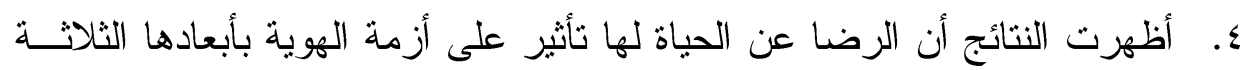

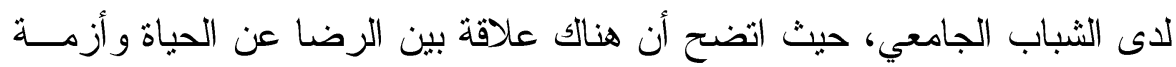

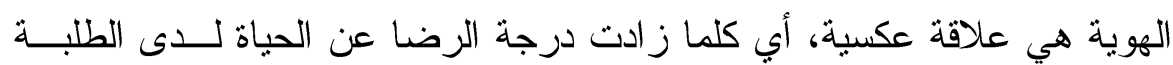
عينة الدراسة، أدي هذا إلى نقص درجة أزمة الهوية، وتعزو الباحثة هذه النتيجة

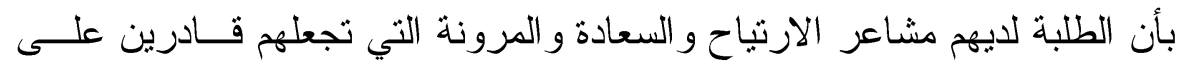

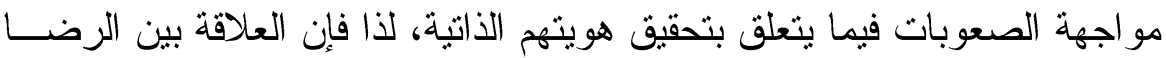


أزمة الهوية وعلاقتها بكل من ثقافة وسائل الاتصال والرضا عن الحياة في ضوء بعض

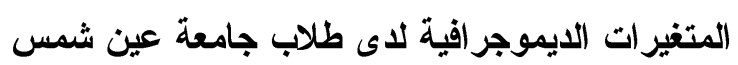

عن الحياة وأزمة الهوية هي علاقة سلبية، حيث أثنار (Huffstetler,2006) أن

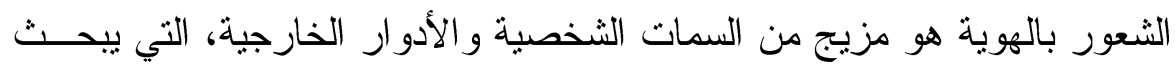

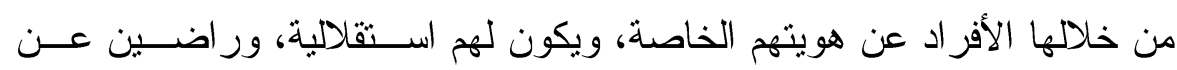

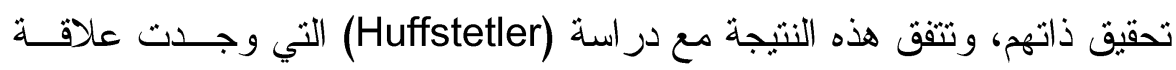
بين الإحساس بالهوية و الرضا عن الحياة، وتختلف نتائج هذه الدر اسة مع در اســـة (Katibi, 2015) الصلابة النفسية وأزمة الهوية، كون الصلابة أحد مفاهيم علم الــنفس الإيجـابي المتعلق بالرضا عن الحياة. 0. أظهرت النتائج عدم وتوجد فروق ذات دلالة إحصائية بين آر اء أفر اد العينة مسن

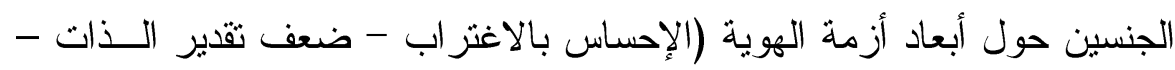

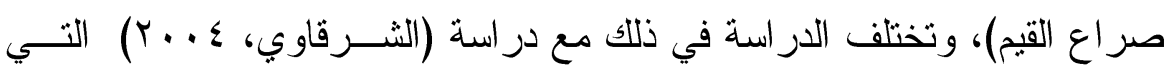

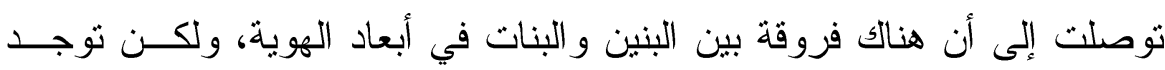
فروق ذات دلالة إحصائية بين أفراد العينة من الجنسين حول (صر اع القيم) كأحد ملامح أزمة الهوية لدى الثباب الجامعي، وكانت هذه الفروق لصالح أفراد العينة

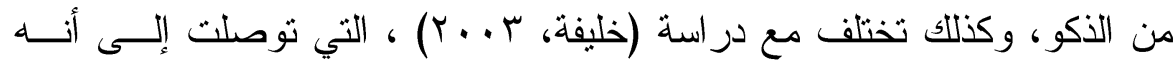
توجد فروق بين الذكور و الإناث من طلاب الجامعة في المفارقة القيمية، ولعـلـل

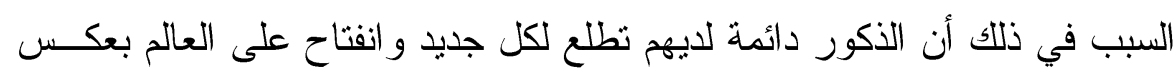

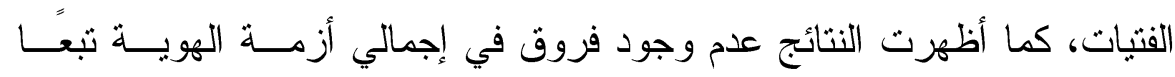

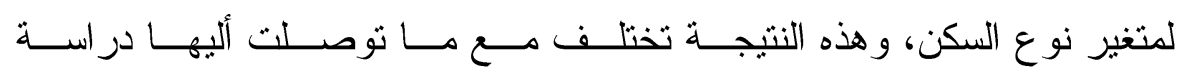

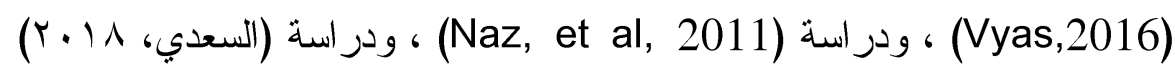
بأن هناك فروف في أزمة الهوية تبعاً لمتغير الإقامة.

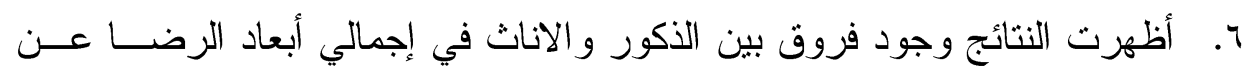
الحياة لصالح الإناث، وتعزو الباحثة ذلك إلى أنه رغم أن طلبة الجامعة يتعايشون 
نفس الظروف الحياتية الاجتماعبة و الاقتصادية، وتكون درجة رضاهم عن الحياة مثقاربة في ظل النمط الثقافي السائد في المجتمع المصري، إلا أنه بلاحظ فيه أن

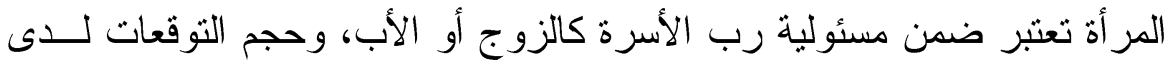
المر أة في مجتمعنا يجعلها تقبل أي شيء ممكن ومتاح، بالإضافة إلــى الاهتمـــام

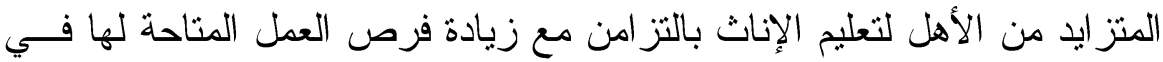
سوق العمل المصري، الأمر الذي قد يعزز شعور الرضـا عن الحياة لدى الإنــاث

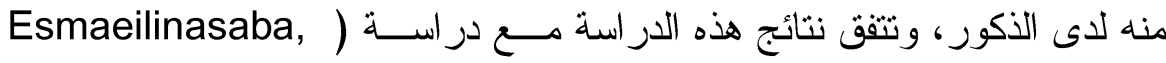
2016) ، ودر اســـــــــ (Al-Attiyah and Nasser2016)، ودر اســـــــــة

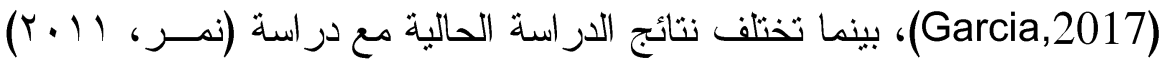
الني بينت عدم وجود فروق ذات دلالة إحصائية في الرضا عن الحياة وفق متغير

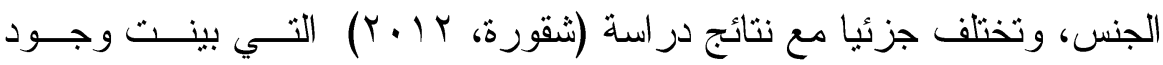

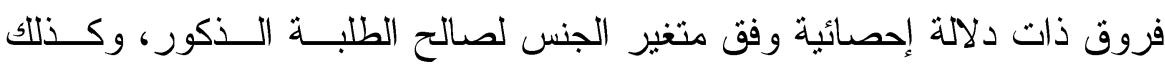

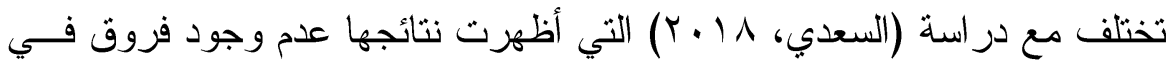

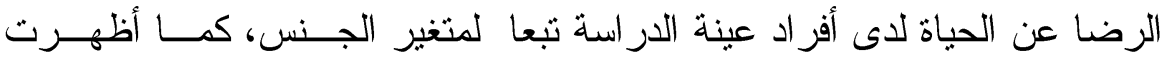

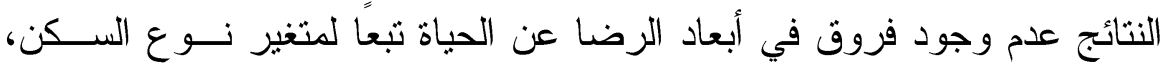
وتعزو الباحثة ذلك بأن الطلبة لديهم مشاعر إيجابية نحو الحباة، ولديهم العلاقــات الاجتماعية و التفاعلية الجيدة، و التي تسهم في تحقيق الإشباع العاطفي لهم، وهــــا

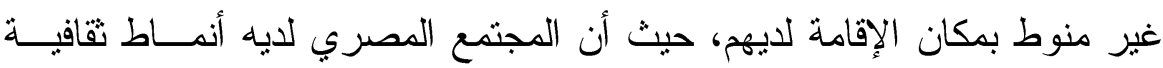
و اجتماعية منشابهة، ولديه نسيج اجتماعي قوي يحافظ على وجــودهم وكيــانهم. وتختلف هذه النتيجة مع در اسة (Branch-Allen, 2016) و التي توصلت بــأن السكن في منطقة حضرية يحقق المزيد من الرضا عن الحياة، وتتفق مع دراســـة

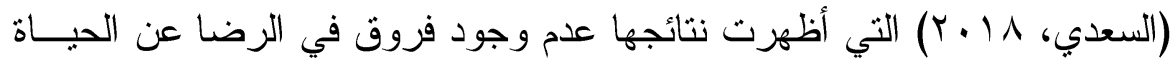
تبعا لمتغير مكان الإقامة. 


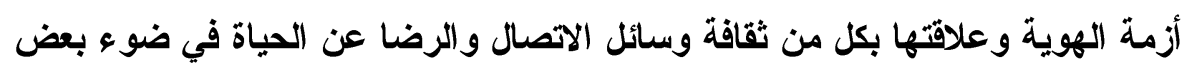

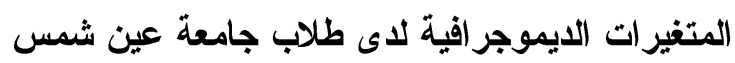

\section{توصياث الار اسة}

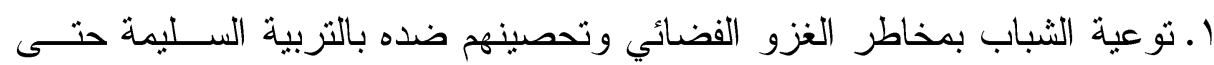
يكون لديهم القدرة على التمبيز بين الغث و السمين.

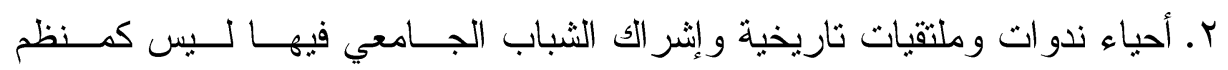
فحسب، و إنما كطرف مشارك لإثر اء البحث العلمي وتتمية إحساســــه بالانتمــاء

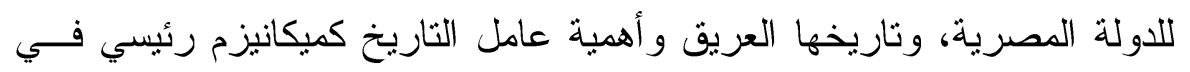
الهوية و الثقافة المصرية. ب. توجيه الثباب من خلال تبصيره بطُرق استغلال التطور التكنولوجي بإيجابياتـهـ بدل اهتمامه بالقشور التي تسلُبه هويته وثقافته العربية الأصيلة.

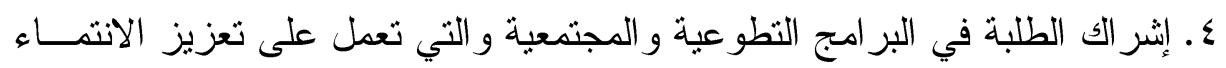

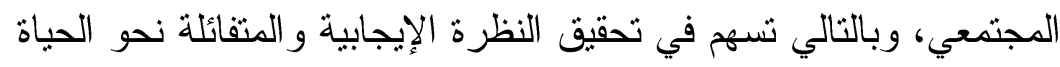


أ/بسنت عدلي حسن محمد

\section{المر (جع}

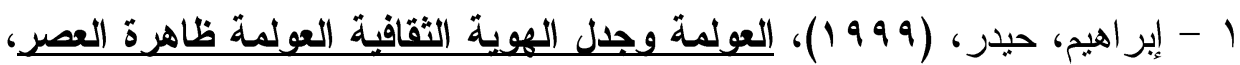
مجلة عالم الفكر، المجلس الوطني للثقافة و الفنون و الآداب، العدد (ب)، الكويت.

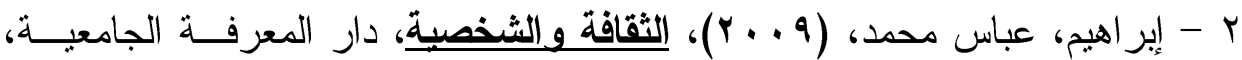

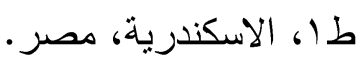

r - ابن منظور، لسان العرب، الجزء السادس، دار المعارف، بدون ثاريخ.

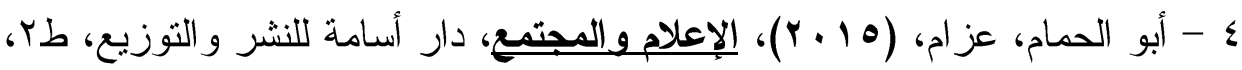
الأردن.

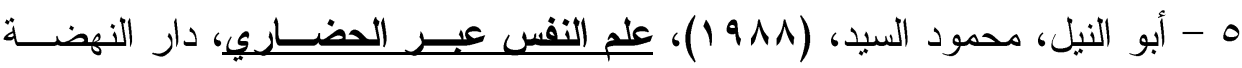

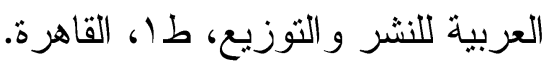

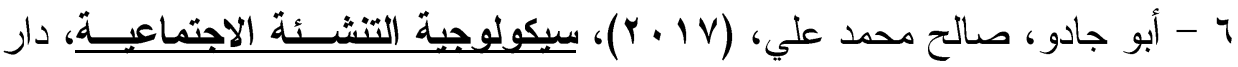
المسيرة للنشر و النوزيع، طس اه، الأردن.

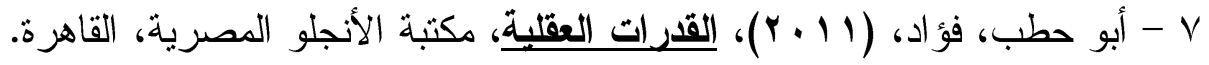

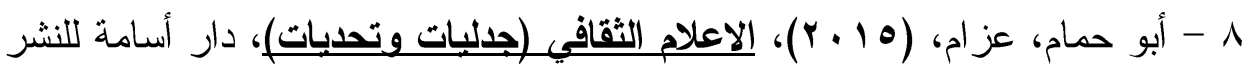

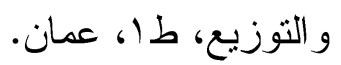

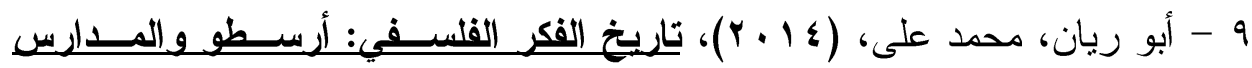
المتأخرة، دار الوفاء، طب، القاهرة.

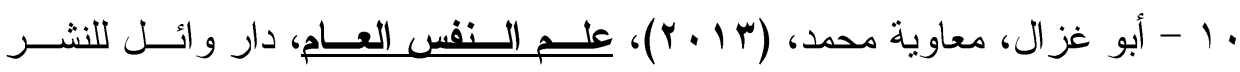

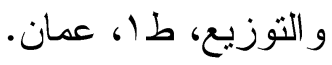

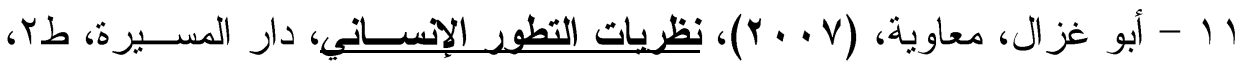
عمان.

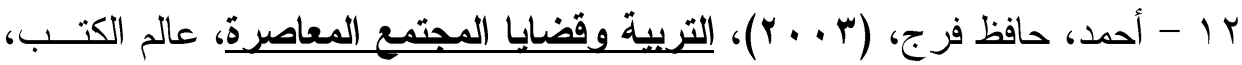
القاهرة.

r.r. العدد الرابع والاربعون (الجزء الأول)

(113)

مجلة كلية التربية- جامعة عين شمس 
أزمة الهوية وعلاقتها بكل من ثقافة وسائل الاتصال والرضا عن الحياة في ضوء بعض

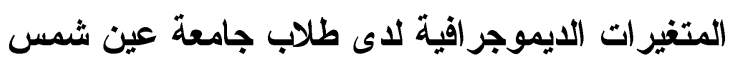

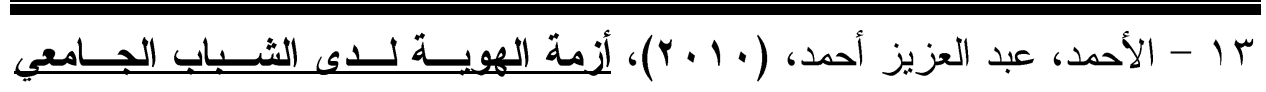

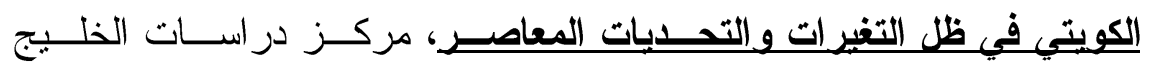

$$
\text { و الجزيرة العربية، العدد (ب^)، الكويت. }
$$

ع ا - استيتية، دلال ملحس، (ع . . ب)، التغير الاجتماعي والثقافي، دار و ائل للنشــر

$$
\text { و التوزيع، الأردن. }
$$

10

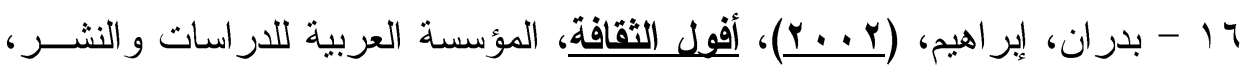
الإسكندرية.

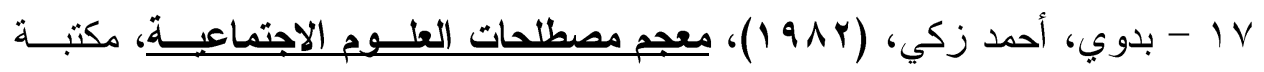

$$
\text { بيروت، بيروت. }
$$

1 1 - البرعي، وفاء محمد، (Y . ب)، دور الجامعة في مواجهة التطرف الفكري، دار المعرفة الجامعية، الإسكندرية.

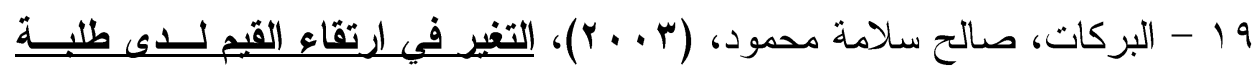

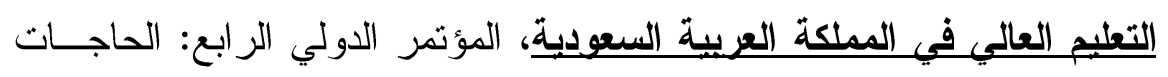

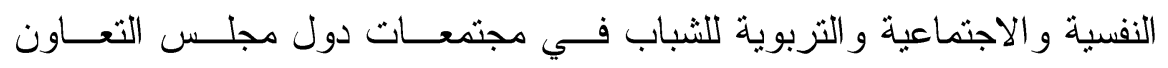
الخليجي، مكتب الإنماء الاجتماعي، الديون الأميري، دولة الكويت.

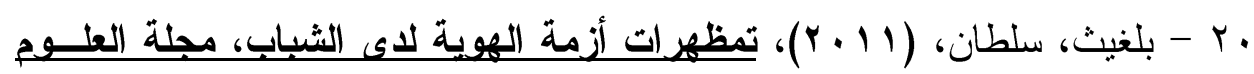

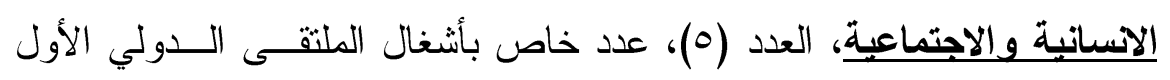

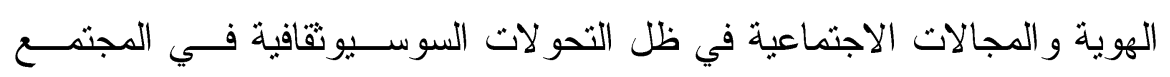

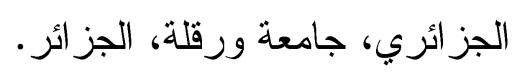

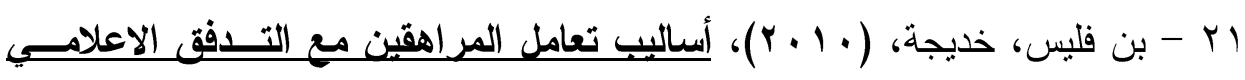

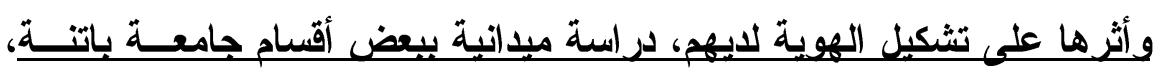

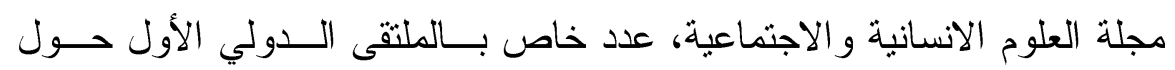

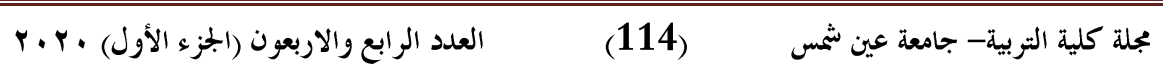


الهوية و المجالات الاجتماعية في ظل التحولات السوسيو ثقافية فــي المجتمـعـع الجزائري، جامعة قاصدي مرباح، ورقلة، الجزائر .

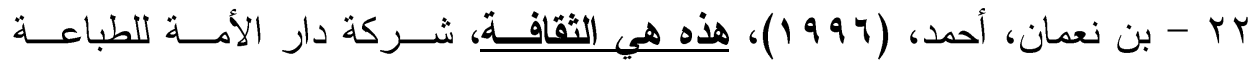
و التزجمة و النشر و التوزيع، برج الكيفان، الجزائر.

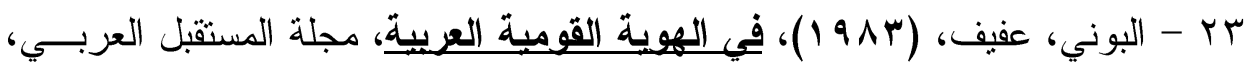

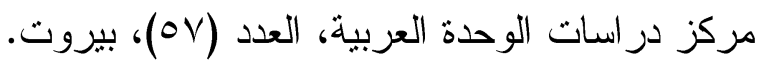

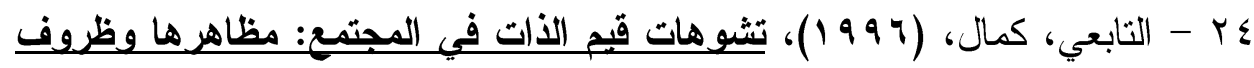

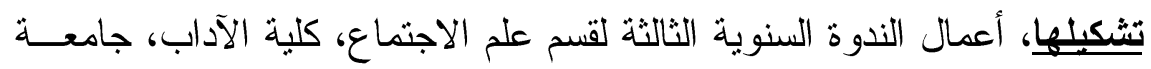
القاهرة.

0 - التويجري، عبد العزيز، (10 ب ب)، الثقافة العربية والثقافات الأخرى، (الطبعــة الثانية)، المغرب: منشور ات المنظمة الإسلامية للتربية و العلوم و الثقافة.

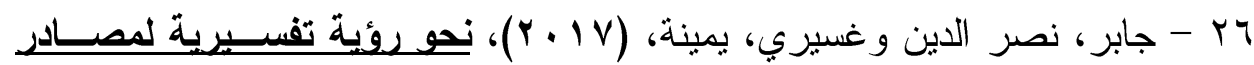

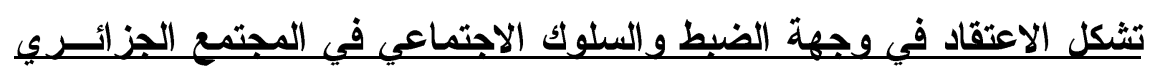

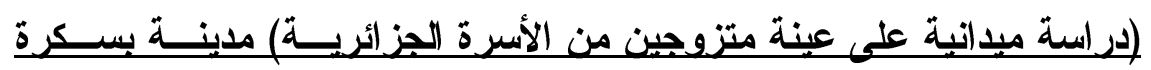
نموذجا، مجلة علوم الانسان و المجتمع، العدد (rr)، الجزائر . TV

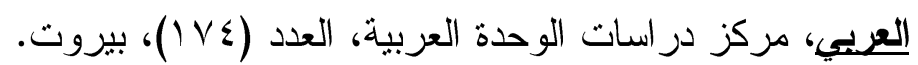

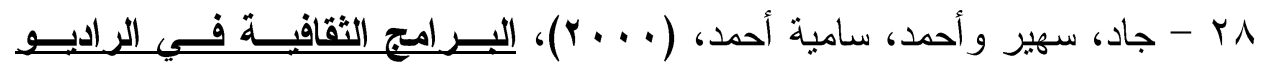
والتلفزيون، دار الفجر للنشر و التوزيع، طا، واه، مصر.

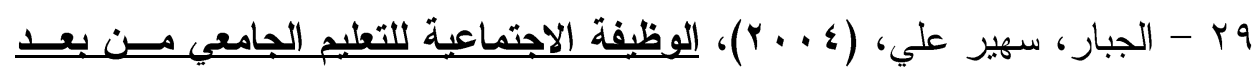
على ضوء التحويلات المعاصرة، مجلة التزبية والتنمية، العدد (• (ب)، القاهرة. 
أزمة الهوية وعلاقتها بكل من ثقافة وسائل الاتصال والرضا عن الحياة في ضوء بعض

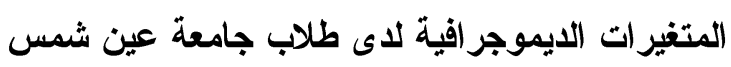

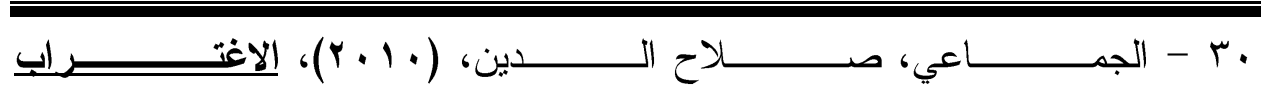

النفسي الاجتماعي وعلاقته بالتو افقى النفسي والاجتماعي، دار زهران للنشــر

$$
\text { و التوزيع، طب، عمان. }
$$

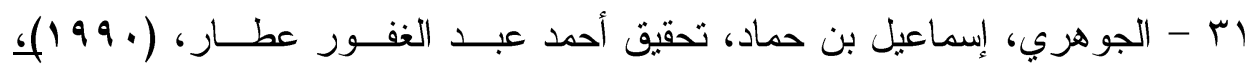

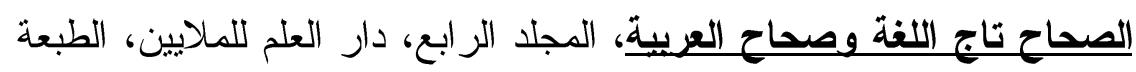

$$
\text { الر ابعة. }
$$

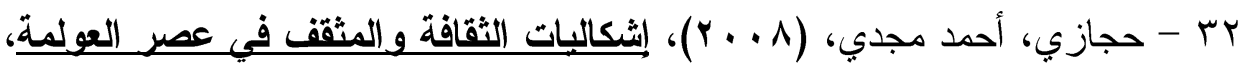
دار قباء الحديثة للطباعة و النشر و التوزيع، القاهرة.

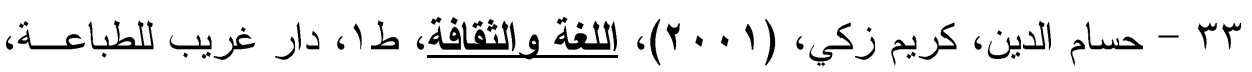

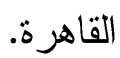

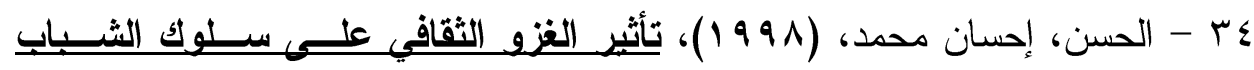

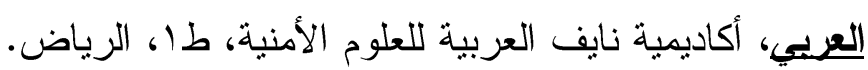

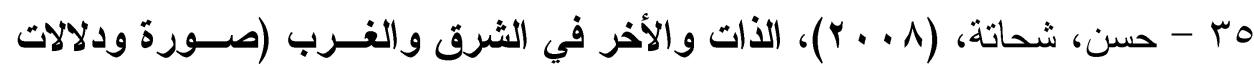

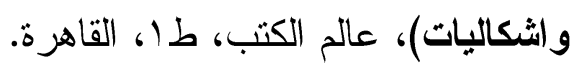

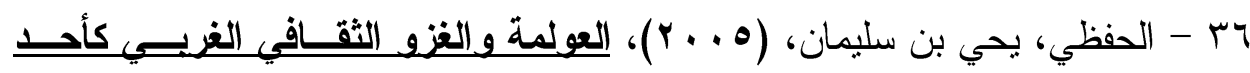

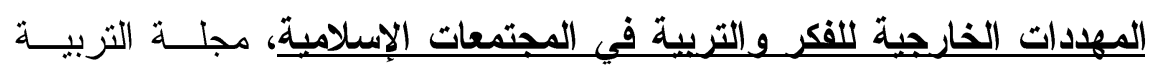

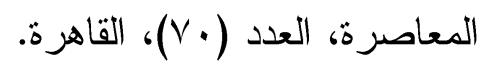

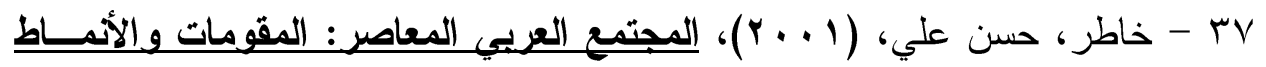

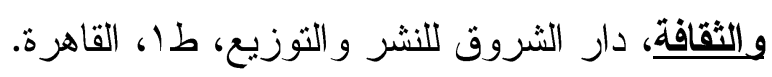

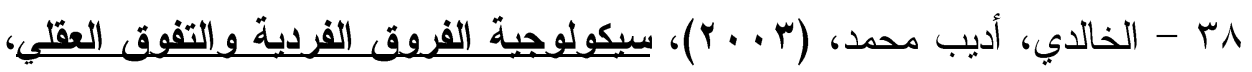

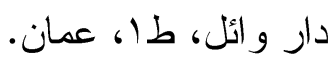

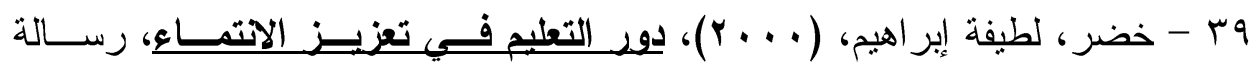
دكتور اه منشورة، عالم الكتب، القاهرة. 


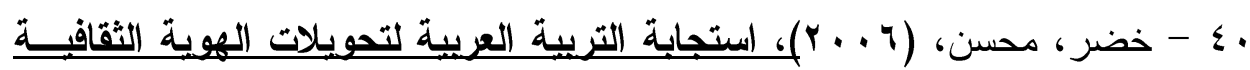
تحت ضغط العولمية، مجلة التزبية وعلم النفس، كلية التزبيــة، جامعــة عــين

$$
\text { شمس، مجلد (1)، العدد (•r). }
$$

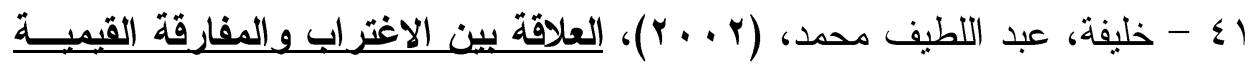

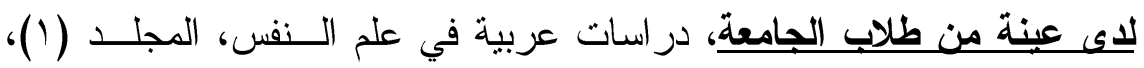

$$
\text { العدد (1) (1) }
$$

r غريب للطباعة و النشر و التوزيع، القاهرة.

r لاي الثباب الجامعي في المجتمعات العربية عامة والمجتمع المصري خاصة، مجلة دراسات عربية في علم النفس، المجلـــ (ع)، العـدد (1)، دار غريــبـ ل ل ل مباعة و النشر ، القاهرة.

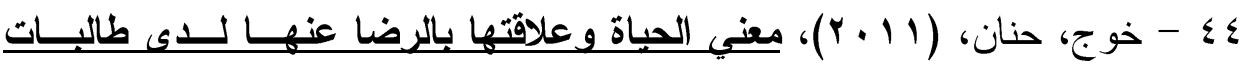

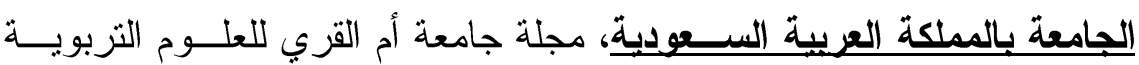

$$
\text { و النفسية، المجلد (r)، العدد (r). }
$$

0؛ - الدسوقي، مجدي محمد، (1 99 1)، دراسة لأبعاد الرضا عف الحباة وعلاقتهــ بعدد من المتغيرات النفسبة لاى عينة من الر اشثدين وصغار السـن، المجلــة

$$
\text { المصرية للار اسات النفسية، المجلد (^)، العدد (•r). }
$$

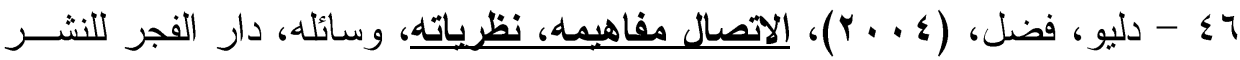

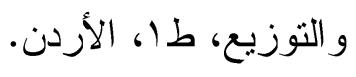

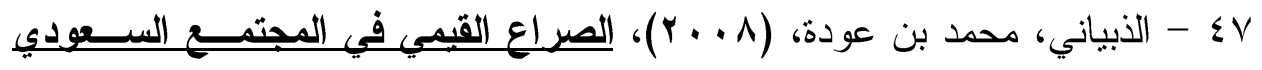
ودور وسائط التريية في علاجه، مجلة مستقبل التربية العربية، المجلـــ (ع ())، العدد (ror)، المركز العربي للتعليم و التنمية، القاهرة. 
أزمة الهوية وعلاقتها بكل من ثقافة وسائل الاتصال والرضا عن الحياة في ضوء بعض

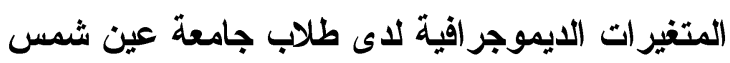

^ـ - الرشدان، عبد الفتاح علي، (Y . . Y)، دور التربية في مواجهية تحلبات العولمة في الوطن العربي، المتلقي العربي حول التربية وتحديات العولمــة، المنظمــة العربية للتربية و التقافة و العلوم.

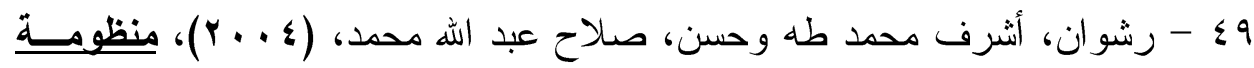
القيم لاى الثباب الجامعي في ضوع التحدي التكنولوجي (در اســـة مبدانبــة)؛

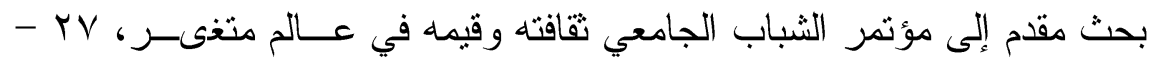

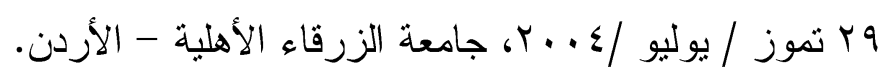

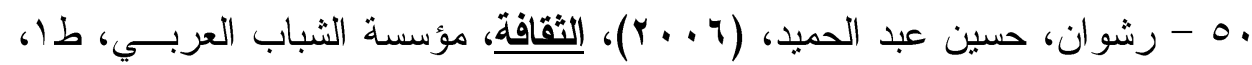

$$
\text { الإسكندرية. }
$$

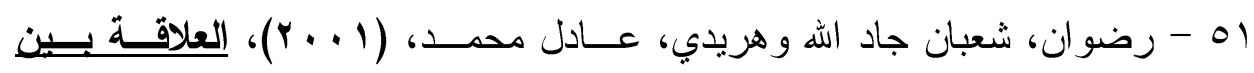

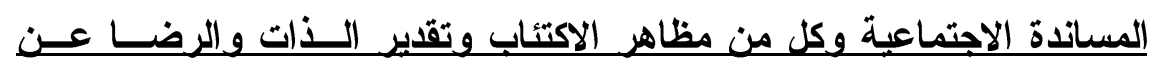

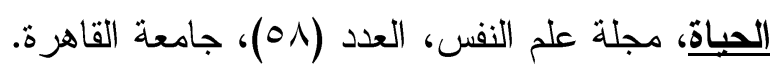
r المصرية للكتاب، القاهرة.

به - الريماوي، محمد عوده، (T . . Y)، علم النفس، دار الميسرة، طس، الأردن.

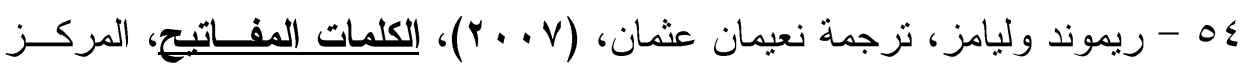

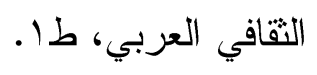

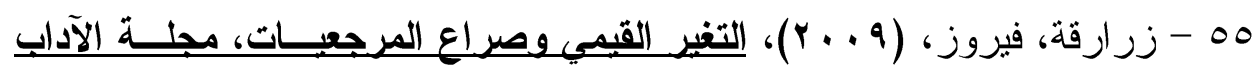
والعلوم الاجتماعبة، عدد خاص بالملتقى الوطني الأول حول التغير القيمي في

المجتمع الجزائري، جامعة فرحات عباس، سطيف، الجزائر.

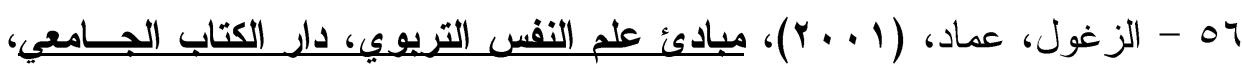

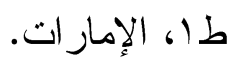




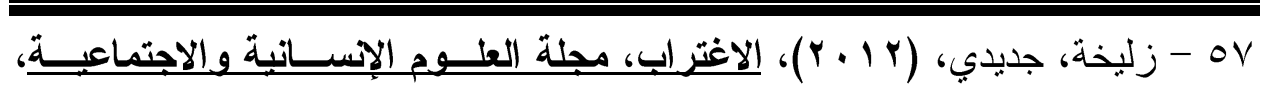

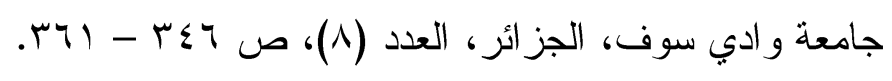

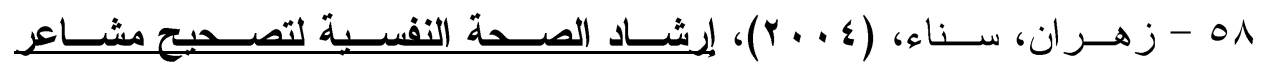

$$
\text { ومعتقـــات الاغتـــراب، عـاءلم الكتب، القــاهرة. }
$$

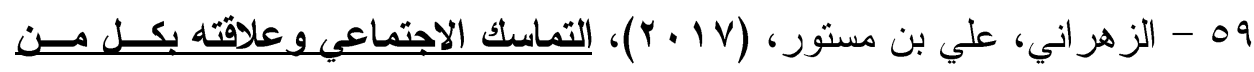

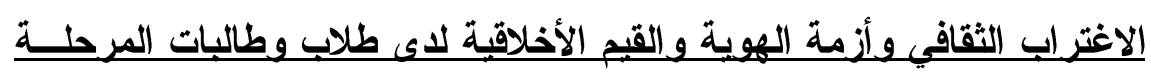

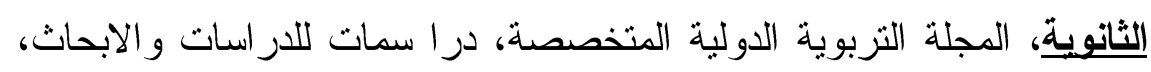

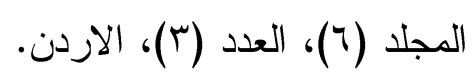

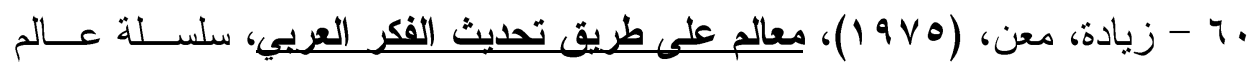

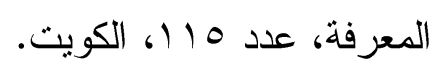

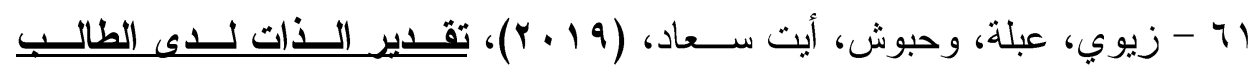
الجامعي: دراسة مقارنة، جامعة قاصدي مرباح - مخبر تطوير الممارسـات

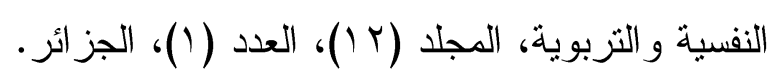

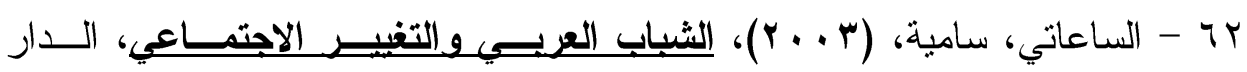
المصرية اللبنانية، القاهرة.

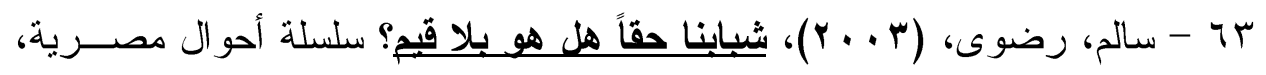

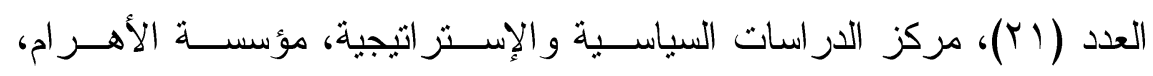

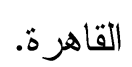

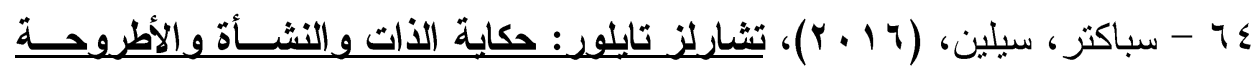

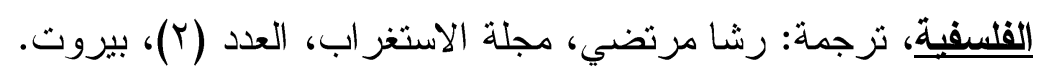

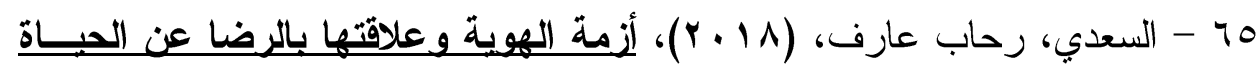

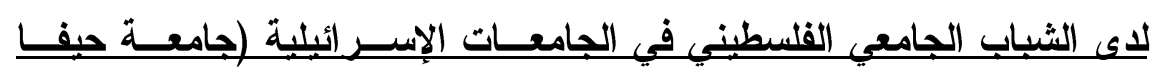


أزمة الهوية وعلاقتها بكل من ثقافة وسائل الاتصال والرضا عن الحياة في ضوء بعض

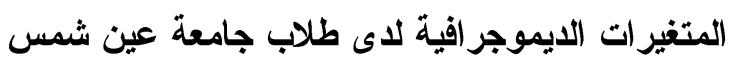

أنموذجما)، مجلة النجاح للأبحاث، العلوم الإنسانية، جامعــة النجـــاح الوطنـــة، المجلد (Yr)، العدد (Y)، نابلس، فلسطين.

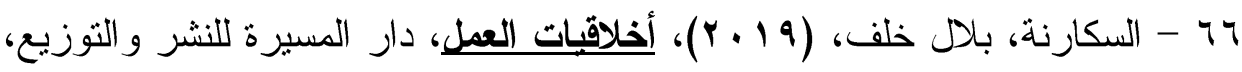
ط9، عمان.

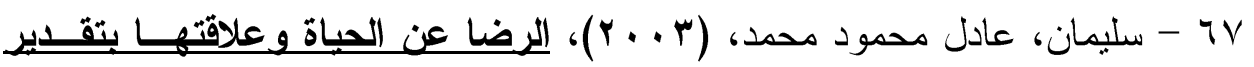

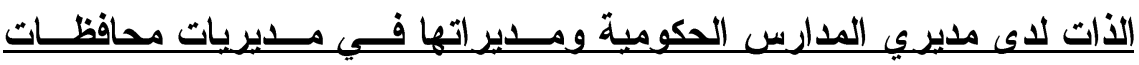
فلسطين الثمالبة، رسالة ماجستير، جامعة النجاح الوطنية، الضفة الغربية.

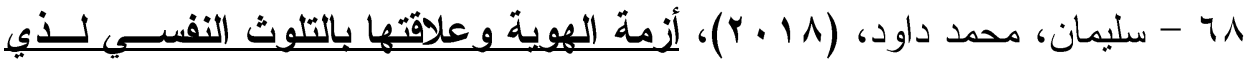

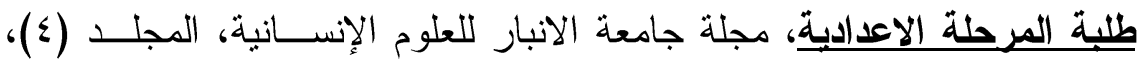
العدد (乏)، العراق.

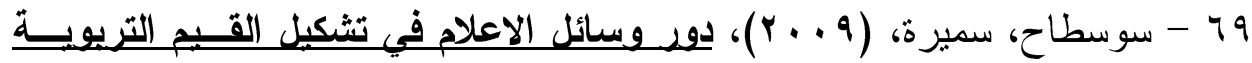
داخل الأسرة الجزائرية - دراسة مبدانبة لتأثثر الاشهار التلفزيوني على القيه، مجلة الآداب و العلوم الاجتماعية، جامعة فرحات عباس، سطيف، الجز ائر.

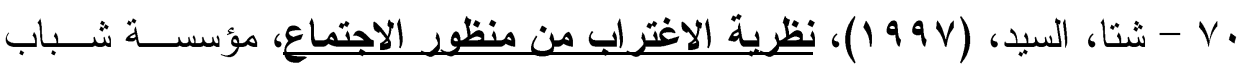

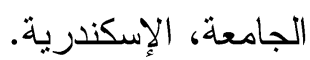

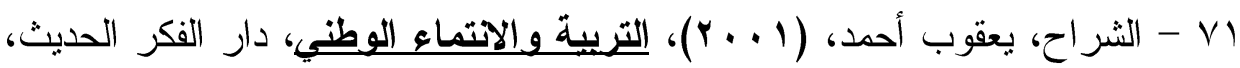
الكويت.

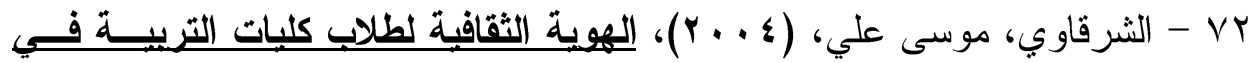

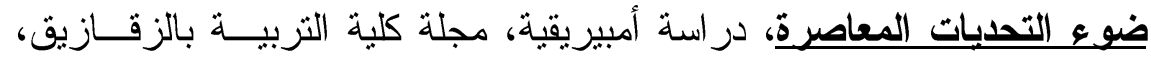

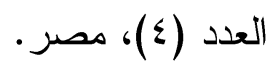

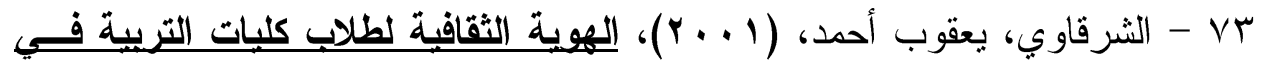
ضوع التحبيات المعاصرة دراسة أمبيريقية، مجلة كلية التربية بالزقازيق، العدد

$$
\cdot 0 ر(\xi V)
$$




\section{أ/بسنت عدلي حسن محمد}

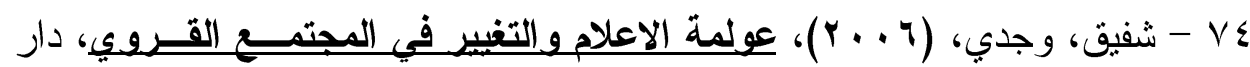
ومكتبة الإسر اء للطبع و النشر و التوزيع، طنطا.

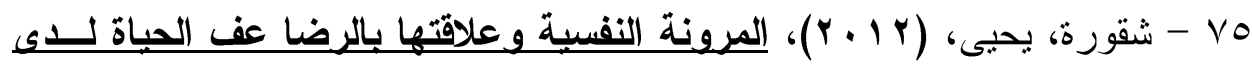
طلبة الجامعات الفلسطينبة بمحافظات غزة، (رسالة ماجستير غير منشــورة.)

$$
\text { جامعة الأزهر، غزة. }
$$

VY - شقير ، زينب محمود، (9 . . Y)، علم النفس الاجتماعي والمشكلات الاجتماعبـة للفردـ والمجتميع، دار الفكر العربي، القاهرة.

- شميمري، فهر بن عبد الرحمن، ( • VV الإعلام، مطبعة الملك فهد الوطنبة للنشر، طا، الرياض.

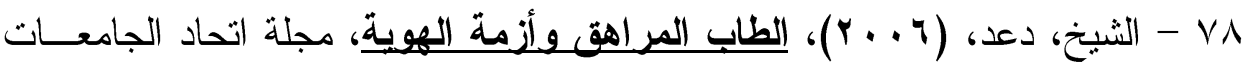
العربية للتزبية وعلم النفس، كلية النزبية جامعة دمشق، المجلد (ع)، العدد (؟)،

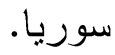

V9 - صالح، محمد علي أبو جادو ، (991 (1)، سيكولوحية التنشئة الاجتماعبــة، دار المسيرة للنشر و الثوزيع، الأردن.

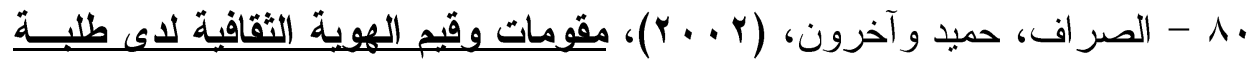
المرحلة الثانوية بدولة الكويث، قطاع البحــوث الثزبويـة و المنــاهج، واز ارة

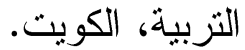

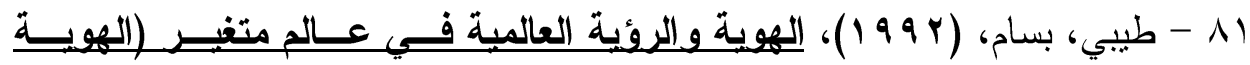
(الثقافية في الزمان)، مكتبة الانجلو المصرية، القاهرة.

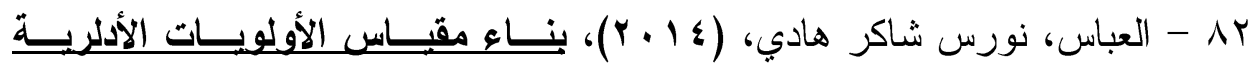

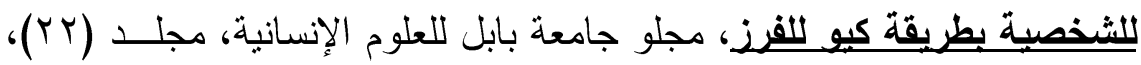

$$
\text { العدد (Y)، العراق. }
$$


أزمة الهوية وعلاقتها بكل من ثقافة وسائل الاتصال والرضا عن الحياة في ضوء بعض

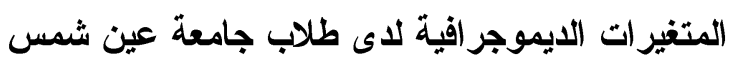

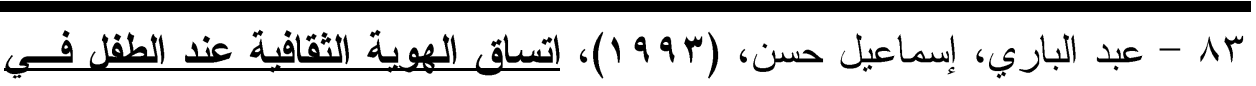
مجتمع متغير، "المؤتمر السنوي السادس للطفل المصري، نتشئنه في ظل نظام عالمي جديد • 1 - ب ا ابريل"، مركز در اسات الطفولة، جامعة عين شمس.

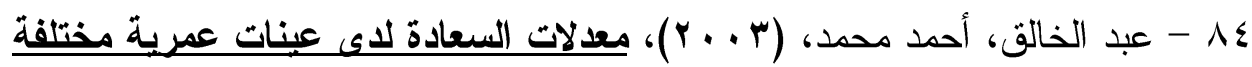
من المجتمع الكويتي، مجلة دراسات نفسية، المجلد (r ()، العدد (ع)، الكويت.

10 - عبد الرحمن، محمد السيد، (991 (1)، نظريات الثخصية، دار قباء، القاهرة.

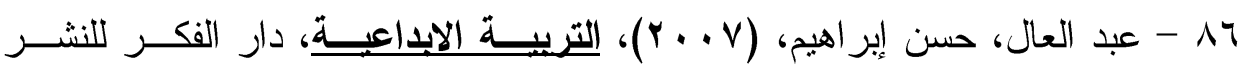
و التوزيع، عمان، الأردن.

NV

$$
\text { الصيرفي، غزة. }
$$

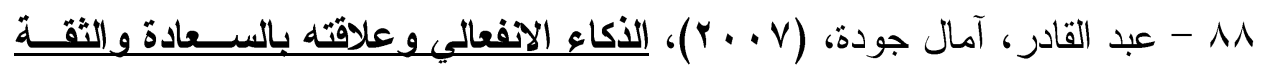
بالنفس لاى طلبة جامعة الأقصىى، مجلة جامعة النجاح للعلوم الإنسانية، المجلد

$$
\text { ( (Y))، العدد (r)، فلسطين. }
$$

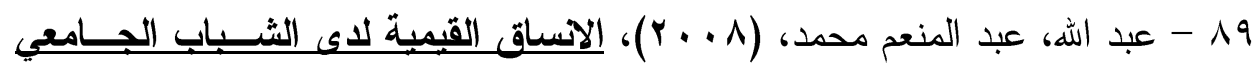

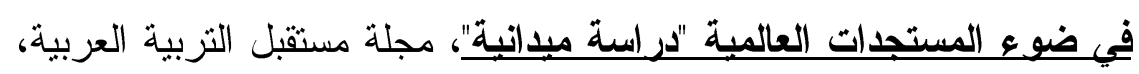

المجلد (ع ()، العدد (9 §)، المركز العربي للتعليم و التنمية، القاهرة.

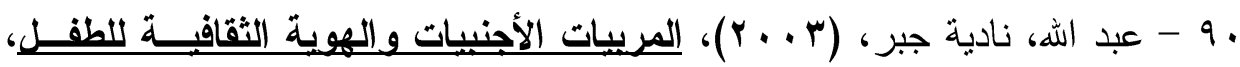

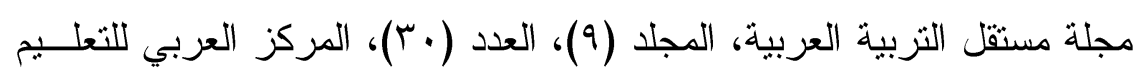

$$
\text { و التنمية، القاهرة. }
$$

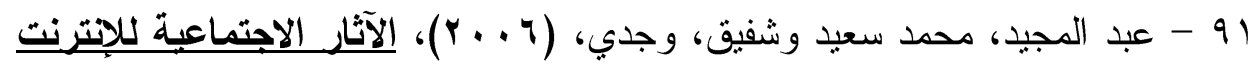
على الثباب، دار ومكتبة الاسر اء للطبع و النشر و التوزيع، طنطا.

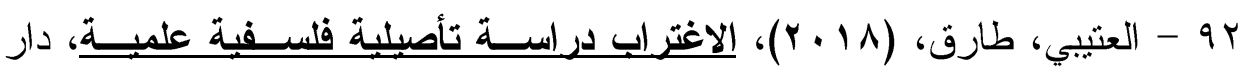
الكتاب الجامعي للنشـر و التوزيع، السعودية.

r.r. العدد الرابع والاربعون (الجزء الأول)

(122)

مجلة كلية التربية- جامعة عين شمس 
بو - العجمي، محمد حسنين، (9 . . ץ)، في اجتماعبات التربية المعاصرة، دار الفكر للنشر و التوزيع، طا، عمان.

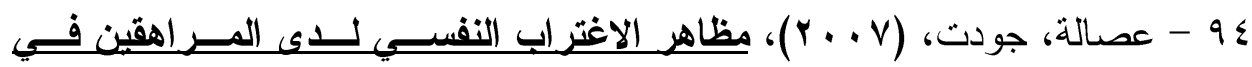
محافظة عكا، (رسالة ماجستير غير منشورة)، الجامعة الاردنية، الأردن.

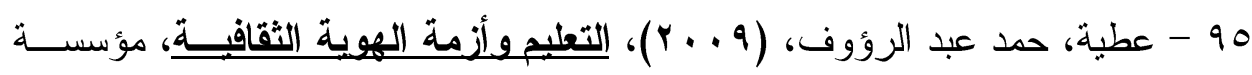
طيبة للنشر و التوزيع، طاه، القاهرة.

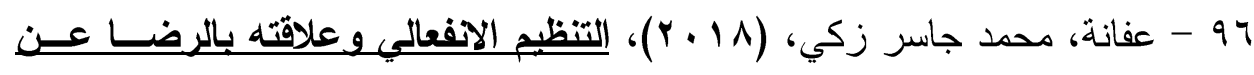

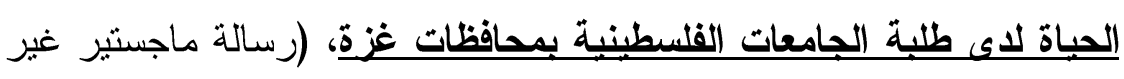
منشورة.)، الجامعة الإسلامية بغزة.

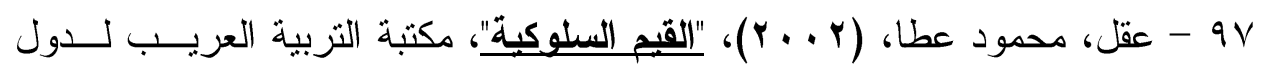

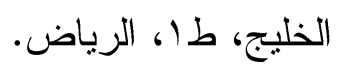

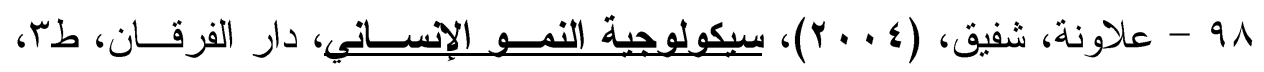
عمان. 99 - علم الدين، محمود، (9999)، ثورة المعلومات ووسيائل الاتصال - التـأثير ات

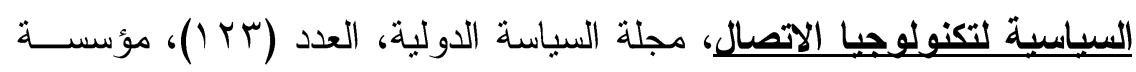

$$
\text { الاهر ام، القاهرة. }
$$

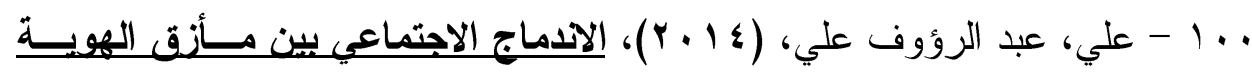

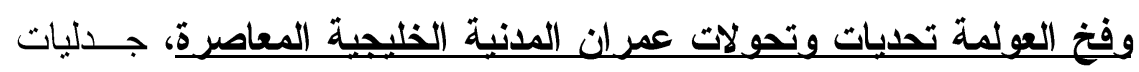

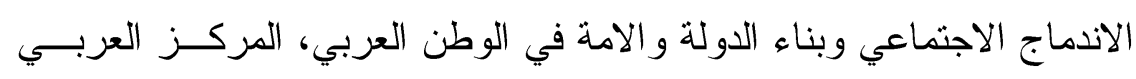
للأبحاث ودر اسة السياسات، بيروت.

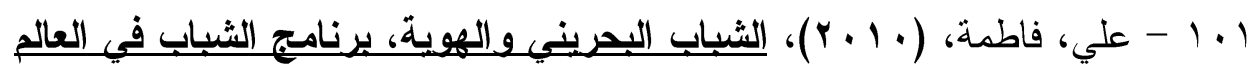

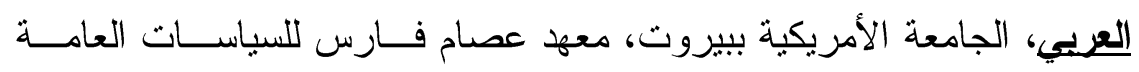
و الثؤون الدولية. 
أزمة الهوية وعلاقتها بكل من ثقافة وسائل الاتصال والرضا عن الحياة في ضوء بعض

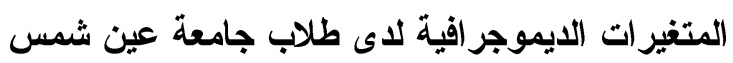

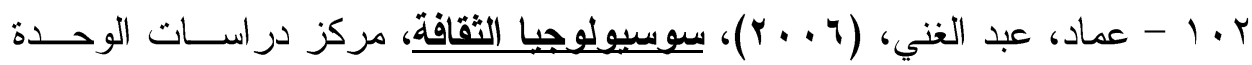

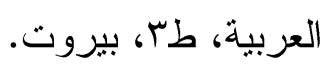

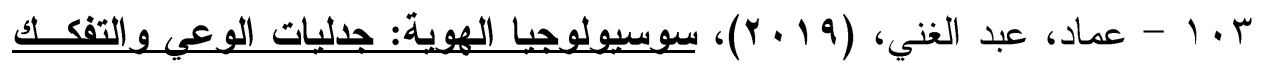

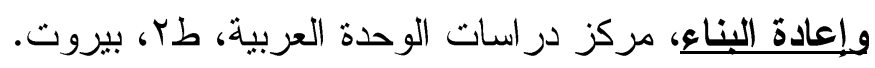

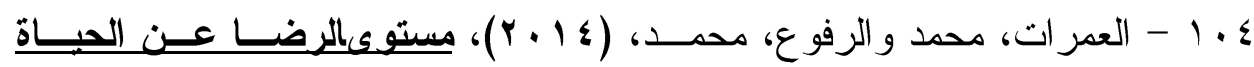
الجامعية وعلاقتها بلرجة تقبير الذات لاى طالبات جامعة الطفيلة التقنية في

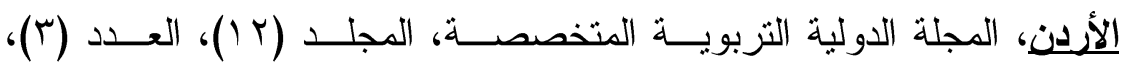
الأردن.

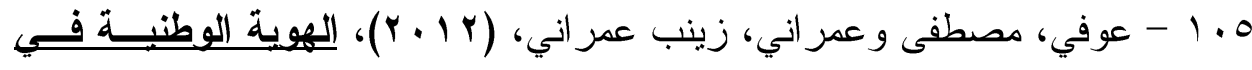

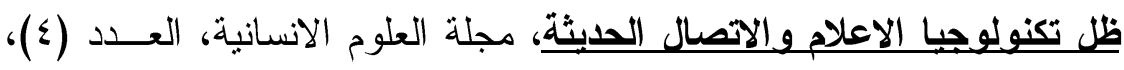
بسكرة، الجز ائر .

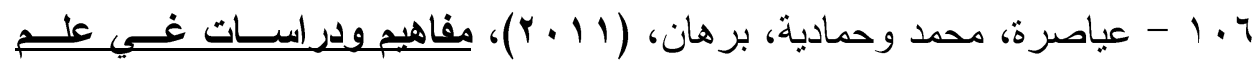
النفس التريوي، دار زهر ان، طاه، عمان.

المراجع الاجنبية

1 - Al-Attiyah, A. and R. Nasser (2016). "Gender and age differences in life satisfaction within a sex-segregated society: sampling youth in Qatar." International Journal of Adolescence and Youth 21(1): 84-95.

2 - Altan, H. Z. (2008). "The Role of Popular Culture in the Identity Crisis Experienced in Puberty."

3 - Andrain, Charles, (1994); Political life and Social change Puxbury press, Second Edition.

4 - Bauman, Z. (1992). "Soil, blood and identity." The sociological review 40(4): 675-701.

5 - Baumeister, R. F., et al. (1985). "Two kinds of identity crisis." Journal of personality 53(3): 407-424 
6 - Berzonsky, M. D. (2008). "Identity formation: The role of identity processing style and cognitive processes." Personality and individual differences 44(3): 645-655.

7 - Berzonsky, M. D. and L. S. Kuk (2005). "Identity style, psychosocial maturity, and academic performance." Personality and individual differences 39(1): 235-247.

8 - Beutell, N. J. (2010). "Work schedule, work schedule control and satisfaction in relation to work-family conflict, workfamily synergy, and domain satisfaction." Career Development International 15(5): 501-518 .

9 - Boyd, D. M. and N. B. Ellison (2010). "Social network sites: definition, history, and scholarship." IEEE Engineering Management Review 38(3): 16-31 .

10 - Branch-Allen, R. and J. Jayachandran (2016). Determinants of life satisfaction in Canada: A causal modeling approach. SHS Web of Conferences, EDP Sciences.

11 - Canada, B. J. (2003). Life Satisfaction and Self-concept of Elderly Living in Congregate and Non-congregate Housing in Knox County, Tennessee, University of Tennessee, Knoxville.

12 - Clench-Aas, J., et al. (2011). "Dimensionality and measurement invariance in the Satisfaction with Life Scale in Norway." Quality of Life Research 20(8): 1307-1317.

13 - Connor, P. E. and B. W. Becker (2003). "Personal value systems and decision-making styles of public managers." Public Personnel Management 32(1): 155-180.

14 - Dameshghi, S. \& Kalantarkousheh, S. (2016). The Relationship between Identity Crisis and Responsibility of, The International Journal of Indian Psychology, 3(1), Issue 2, 97- 109.

15 - Desjarlais, V. W. (2005). Forgiveness, affect and life satisfaction among community-dwelling rural elders: A correlational study, Capella University. 


$$
\begin{aligned}
& \text { أزمة الهوية وعلاقتها بكل من ثقافة وسائل الاتصال و الرضا عن الحياة في ضوء بعض }
\end{aligned}
$$

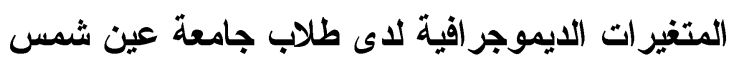

16 - Dias, P. C. and I. Cadime (2017). "Protective factors and resilience in adolescents: The mediating role of selfregulation." Psicología Educativa 23(1): 37-43.

17 - Diener, E. (2000). "Subjective well-being: The science of happiness and a proposal for a national index." American psychologist 55(1): 34.

18 - Diener, E., et al. (1997). "Recent findings on subjective wellbeing." Indian journal of clinical psychology 24: 25-41.

19 - Diener, E., et al. (1999). "Subjective well-being: Three decades of progress." Psychological bulletin 125(2): 276.

20 - Diener, E., et al. (2003). "Personality, culture, and subjective well-being: Emotional and cognitive evaluations of life." Annual review of psychology 54(1): 403-425.

21 - Dombrovskis, A. (2016). IDENTITY AND AN IDENTITY CRISIS: THE IDENTITY CRISIS OF FIRST-YEAR FEMALE STUDENTS AT LATVIAN UNIVERSITIES AND THEIR SOCIODEMOGRAPHIC INDICATORS. Proceedings of the International Scientific Conference. Volume I.

22 - Dorahy, M. J., et al. (1998). "A cross-cultural analysis of religion and life satisfaction." Mental Health, Religion \& Culture 1(1): 37-43 .

23 - Erikson, E. H. (1980): Identity and the life Cycle. New York: W.W. Norton.

24 - Esmaeilinasaba, M., et al. (2016). "Emotion regulation and life satisfaction in university students: Gender differences." Proceedings from ICEEPSY 2016: 7th.

25 - Feather, N. T. (1994). "Values, national identification and favouritism towards the in-group." British Journal of Social Psychology 33(4): 467-476.

26 - Feinstein, B. A., et al. (2013). "Negative social comparison on Facebook and depressive symptoms: Rumination as a mechanism." Psychology of Popular Media Culture 2(3):

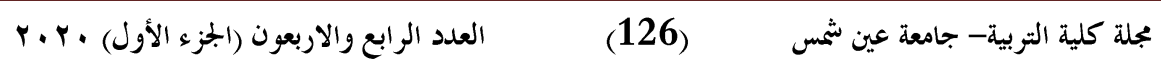


أربسنت علي حسن محمد

161 .Bergagna, E. and S. Tartaglia (2018). "Self-esteem, social comparison, and Facebook use." Europe's journal of psychology 14(4): 831.

27 - Franken, R. E. (1994). Human Motivation. California: Brooks Cole publishing company.

28 - Garcia, D., et al. (2017). "Italian and Swedish adolescents: differences and associations in subjective well-being and psychological well-being." PeerJ 5: e2868.

29 - Goth, K. Foelsch, P. Müller, S. Birkhölzer, M. Jung, M. Pick, O. \& Schmeck, K. (2012). Assessment of identity development and identity diffusion in adolescence Theoretical basis and psychometric properties of the selfreport questionnaire AIDA, Child and Adolescent Psychiatry and Mental Health, 6(1), 6- 24.

30 - Gouveia, V. V., et al. (2009). "Life satisfaction in Brazil: Testing the psychometric properties of the satisfaction with life scale (SWLS) in five Brazilian samples." Social Indicators Research 90(2): 267 .

31 - Grindeland, M. and C. Harrison (2012). The power of social networking for women research study, Accessed.

32 - Haller, M. and M. Hadler (2006). "How social relations and structures can produce happiness and unhappiness: An international comparative analysis." Social Indicators Research 75(2): 169-216.

33 - Harzer, C. and C. Ehrlich (2016). "Different forms of life satisfaction and their relation to affectivity".

34 - Hengehold, L. (2018). Simone de Beauvoir's philosophy of individuation: the problem of the second sex, Edinburgh University Press

35 - Huffstetler, B. (2006). Sense of Identity and Life Satisfaction in College Students, Doctoral Dissertations, University of Tennessee, Knoxville Trace: Tennessee Research and Creative Exchange. 


$$
\begin{aligned}
& \text { أزمة الهوية وعلاقتها بكل من ثقافة وسائل الاتصال و الرضا عن الحياة في ضوء بعض }
\end{aligned}
$$

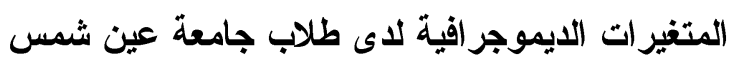

36 - Katibi, M. (2015). Psychological Rigidity and Its Relationship with the Identity Crisis (A Field Study on a Sample of Damascus University Students), Journal of Tashreen University for Scientific Researchers and StudiesSeries of Arts and Humanities, 37 (2), 151-166.

37 - Laing, R., Self and Others (1997), (Britain: Penguin Books), p.35 .

38 - Les:ie L.z, (1999), Value systems changes resulting from a media an ethic course: A postmodern perspective.

39 - Light, H. K. (1985). "Education and Income: Significant Factors in Life Satisfaction of Farm Men and Women." Research in Rural Education 3(1): 7-12.

40 - Mahanta, D. and M. Aggarwal (2013). "Effect of perceived social support on life satisfaction of university students." European Academic Research 1(6): 1083-1094.

41 - Mahmoud, A. (2011). The Identity Crisis among Students of the Preparatory Stage, Journal of Educational and Psychological Researches, (31), 1-24.

42 - Maier, H.W. (1995); Three Theories of Child Development, HarperCollins.

43 - Meeks, S. and S. A. Murrell (2001). "Contribution of education to health and life satisfaction in older adults mediated by negative affect." Journal of aging and health 13(1): 92-119.

44 - Mehmood, T. and M. Shaukat (2014). "Life satisfaction and psychological well-being among young adult female university students." International Journal of Liberal Arts and Social Science 2(5): 143-153.

45 - Meléndez, J. C., et al. (2009). "Psychological and physical dimensions explaining life satisfaction among the elderly: A structural model examination." Archives of gerontology and geriatrics 48(3): 291-295. 
أزبسنت عدلي حسن محمد

46 - Miville, M. L., et al. (2000). "Exploring the Relationships Between Racial/Cultural Identity and Ego Identity Among African Americans and Mexican Americans." Journal of Multicultural Counseling and Development 28(4): 208-224.

47 - Mohammadrezaie, E., et al. (2011). "The effect of cultural capital of families on youth religious identity." ProcediaSocial and Behavioral Sciences 30: 1736-1741.

48 - Mroczek, D. K. and A. Spiro III (2005). "Change in life satisfaction during adulthood: findings from the veterans affairs normative aging study." Journal of personality and social psychology 88(1): 189 .

49 - Nair, K. R., et al. (2015). "Identity crisis among early adolescents in relations to abusive experiences in the childhood, social support and parental support." Journal of Psychosocial Research 10(1): 167.

50 - Naz, A. Khan, W. Hussain, M. \& Daraz, U. (2011). The Crises of Identity: Gloalization and its Impacts on Socio-Cultural and Psychological Identity Among Pakhtuns of Khyber Pakhtunkhwa Pakistan, International Journal of Academic Research in Business and Social Sciences, April 2011, 1(1), 1- 11

51 - Olson, E.T. (2009). Self-Personal Identity, University of Sheffield, UK

52 - Park, H. (2019). "A model of identity development: Lifecourse narratives of North Korean youth resettling in South Korea." Journal of adolescence 76: 162-172.

53 - Paschali, A. and G. Tsitsas (2010). Stress and life satisfaction among university students-a pilot study. Annals of general psychiatry, BioMed Central .

54 - Paul, E. \& Upadhyaya, H. (2017). Gender Wise Relationship between Value and Self Identity of High School Students, The International Journal of Indian Psychology, 4(88), Issue 2, January-March, 173- 


$$
\begin{aligned}
& \text { أزمة الهوية وعلاقتها بكل من ثقافة وسائل الاتصال و الرضا عن الحياة في ضوء بعض }
\end{aligned}
$$

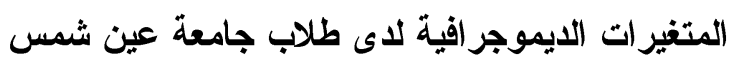

55 - Pavot, W. and E. Diener (2008). "The satisfaction with life scale and the emerging construct of life satisfaction." The journal of positive psychology 3(2): 137-152.

56 - Proctor, C. L., et al. (2009). "Youth life satisfaction: A review of the literature." Journal of happiness studies 10(5): 583630.

57 - Rahul Jain (2008); globalization of communication technology and youth culture in the context of India., international Peace research association (IPRA) 22ND global conference, leuven, Belgium, 15-19 July.

58 - Satchell, c., Shanks, G., Howard, S. \& Murphy. (2011). Identity crisis: user perspectives on multiplicity and control in federated identity management, Behaviour \& Information Technology, 30(1), 51-62.

59 - Schyns, P. (2002). "Wealth of Nations, Individual Income and Life Satisfaction in 42 Countries: A Multilevel Approach." Social Indicators Research 60(1-3): 5-40.

60 - Seghieri, C., et al. (2006). "The richer, the happier? An empirical investigation in selected European countries." Social Indicators Research 79(3): 455-476.

61 - Shibly, S. (2013). The Effect of Using the Internet in the Value Conflict and the Identity Crisis Among University Youths, Unpublished doctoral dissertation, Damascus University.

62 - Van Praag, B. M., et al. (2003). "The anatomy of subjective well-being." Journal of Economic Behavior \& Organization 51(1): 29-49.

63 - Veenhoven, R. (2012). Happiness: Also known as "life satisfaction" and "subjective well-being". Handbook of social indicators and quality of life research, Springer: 63-77. 